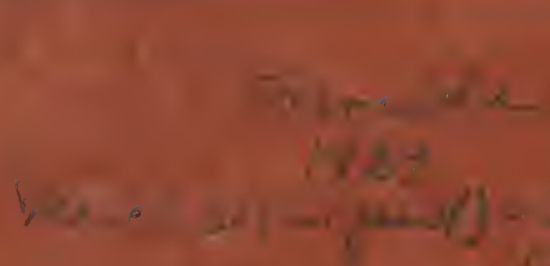


Bermuda

$\times ?$

3-30-29 Datura Ptramonimm, $L$

p. 340. Dead stallas slaceysemain I seed ports nery hell hars been

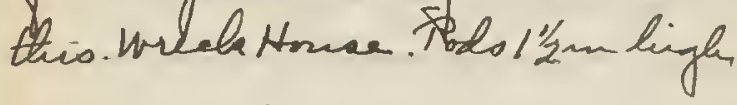

3-30-29 Alsine Baldurinii, G. T. small Fl. Wreck till pata alneg sile v vee top. Lis. mudulate.

3-30-29 Verbarcum Thafosust. fo $34 x$ Flufr. Wrechtowe. Selsalent cytindrical. Corolla whte urvely rutside (A) an reder plant lf margins becurent on at. (B) young jolante ef maysino less dechnentubaal If petirlos nt winged. 
3-30-29 Helirtropium curaravicum L. Fl o fr. Wreck till where de alierts

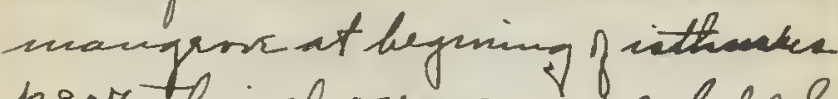
psor this aleogrous subeg ind to eaxt f B.r. Condla has not yellow eye. Fach lfon main ats. has

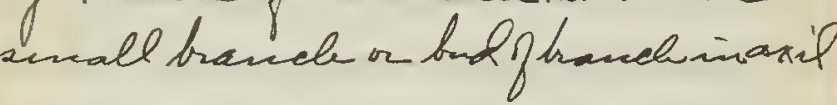

3-30-29 Boursingaultia bollbider. $* 13 \%$

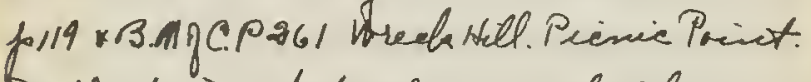
noflep pr. zo tutercle imax lo glos.

$3-30-29$

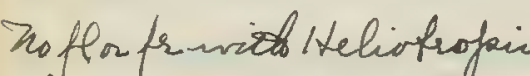
afin. Young planto exbecty ford.

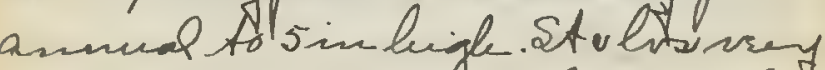
silvery som ofy. Thebly coveref $28 x)$

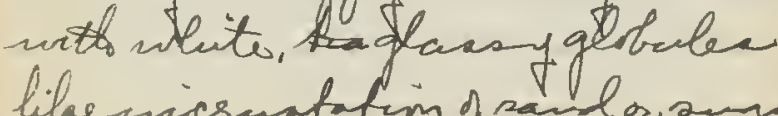
lilas wicruatstim of sand ou su jas. Lroaft. entire. Loneuones oforate

Hode inx $\frac{5}{8}$ in romel at afare

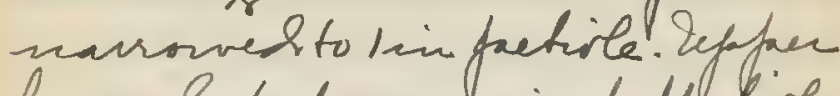
hs. val atrutsand size tut phetirle

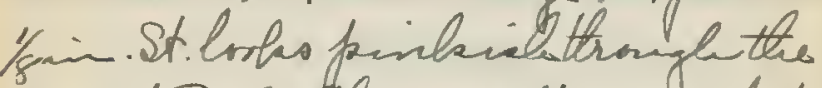
senrf. Prof DChenopodiaceale but B.FPB. 甶114.

9-10-29 Salicarnia purennin, Mill influte nueksill dinic At.and

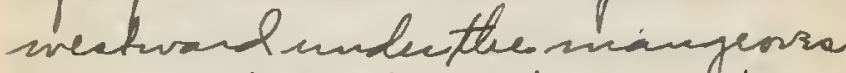
aturlant. Concisto of trailing It.s

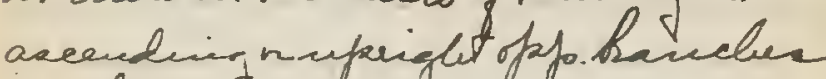
unt jisto $1 / 4$ in ling

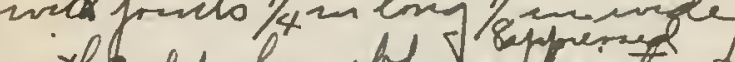
with b offo. low. of tube poonts at utaten

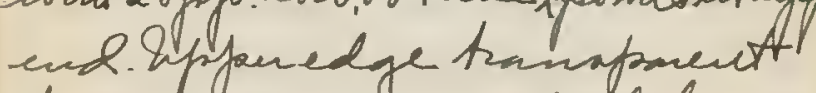
freming a captin which loner end next jint sit. So separate seale repreventing los. 2 ofo hado often found at know 8 jelestetion 
3-30-29 Parretana floudana, Nutt p106. Flvyonng fr. Wreh will Pe-nie Pt. vales on wall at lenvethergahm st. have al ght prinbiah tinge. stor ho finely puberulent $v$ thes sonce what deniging to touch.

3-30-29 Verhena bonaremsiat. p811 Fl. Wreek toure. 4 ft. St. oharfoly 4 -angee? schanneled in the 2 op po aid (alt urth hos. Viltow hurante turagh Les asdece. Brats lanceslate aceuminate atiphany, ciliate, purfatial onedgen 4 mm. long rontoffing calys by the coarar vistfjuttan delecate" Corrla tube 4 mon. ito hanb-8-4 munvide. Stejima z-anequal lobes: I blent. the the apriular v analler. The 4 stanens insertel at 2 difg. heugeti niteste.

3-30-29 Phentyolancerlata, L. 359 Top $q$ meek till Flvfs. Colyx loter that the y are reflexed or preadin not erident to eye. Pixis circun scissile well below sindele.

3-30-29 Cabile lancerlata O.E. Scluelz. p153. Fly fr. Hreak Nonae. Sud in efyeer joint ascending, in lover joint jouduloue.

$x$ ?

3-30-29 Apium Pextoselinumen L. 10275 Fr. mon hes matere. Wreah tonese Imshece bacts usually' sometives 2. Invrlucelbate scanisureargines

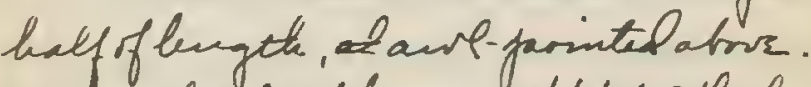

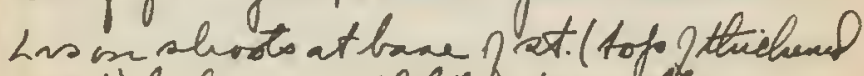
root) lork y ranell lital pardey. 
3-29-29 Melilotur alba. Deav to ing Flv young ps. Middle P'l bet valley

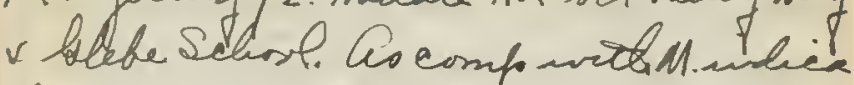
haaseandere $9 M \eta$ h.P. 404 and plact has blinh ratter than yellow islecast but woned te has to diatinguiah wachent $f_{2}$ fr Pacences to 4 in long hosely fruste? ofite rhile Mindica has sacemen winlongelnely fruited. 4-2-29,62140,

4-1-29 Piarópua crassifaer, Brettox 665 ho flo s Dermalike Maral Each lf. sutterdel byat bart one

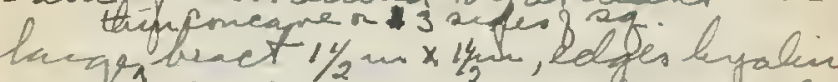
\& ruffled, 3 lobe lat top witt middle lobe subarbicula completely orsat

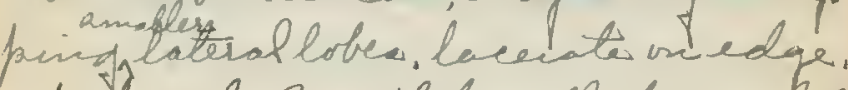
st sheathel writh brodely lanceretos heact $1 / 2$ in long. Kevep of ho at int de of new shost (2xint

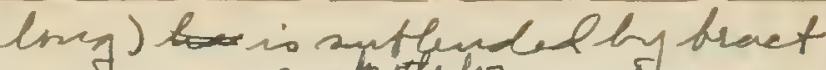

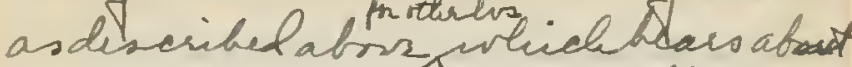
$1 / 3$ distance helmapex a flattirle hinear, lancerlate applen lage inlons which expandonto aruall spativete tip. 2othis the begin ga new shist?

4-1-29 Cuchistea viginica, Preal. p4s Devonalies Marab. In smecares faint serns i vishaia jiat begis ming. Lis witt a littl brom sernt on buck. Imacic green veins me the hijht yreen shoving areolae nexthe mil-rit rerystuking. Lt more

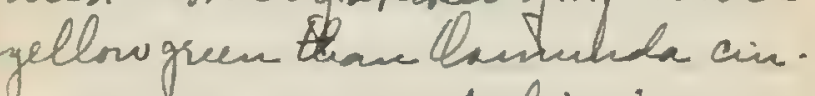
anca $v$ rut ab.

4-1-29 Drypotirio nasu-lia C. Clnetexven fof an. Devarahira March rosare. Vinileto not frael. Siftly 
puhercenty minutely glandela heneatsitidgen? seymento revrlute

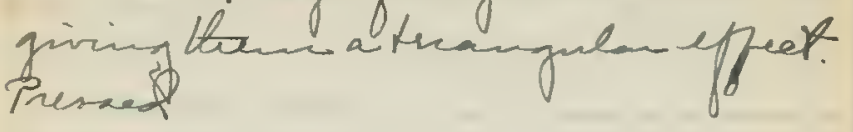

$4-1-29 \times$

Dermalire Marah. Do avi. Bydere. would seern to be Dryojateris Thelyfaterio putwort in e peetas that hisha athome. Veins nece forlnel. Puinar reysuat atalkes and crondal as clovely tovetter that the lowe to mente at leact over la o. Shi et harry perbapolightey gladduld

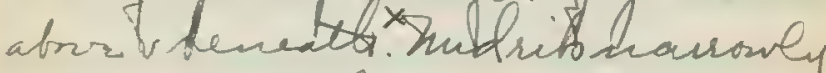
deefoprove Rubaryatrve. "Rut P nof nearly somale so as $D$. normalia $74-1-29$. Blade $7 / 2 / 2$ in $x^{46}$ in rate, wideat about mudelle. Atbane 2 in mish, at next penmae abre $3 \%$ in wide. Crlor yellmoligreer

lebe D. nomalis i 4-1-29 but by Prisher

4-1-29 Brehmeria cylindrica, trilld

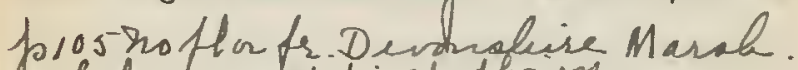
plentos tationsenthaing.

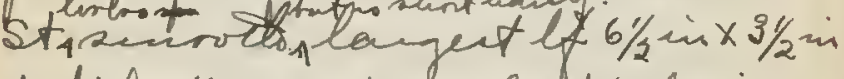
futiole 1/4 in, spanshy offphaing

4-1-29? Verhena scahra, Valel. p310 n flor fr. Dermalie Maral.

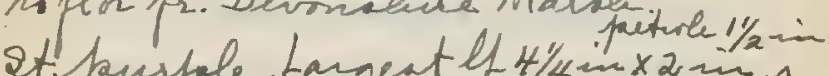
et: purfale Largent ef $4 / 4$ in $\times 2$ in 1 irlegdintate. Lns 3-nervelat bace and Valupied deenuent.

$4-1-29^{?} Q_{2}^{\prime}$

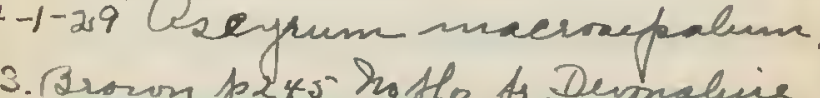
Marak notplentiful. 
$4-1-29$

Acrotichum excelumn, Maxon Commonda regalia,

Oamunda cunsunomea. 2 allinDevonalire Marale.

4-1-29 Persicaria punctata. Suall pirr. In flo fs. Devonalire Marale.

$4-1-299^{?}$ Be iera Drabe p348 (Markel as foum Q1927 but woced frume $4-2-29$ the (227. sforemen) ho fres th Demall

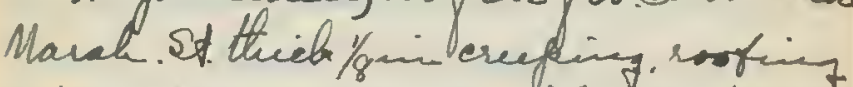
at modes Lns opp, sesile, spatulat $10 \mathrm{~mm} x 5 \mathrm{~mm}$ estire ex eeptle tew vin low heeth at opex pemetite apris b bereat (20x) whrlelplant glabene

4-1-29? 2on Tonardio refaena DC

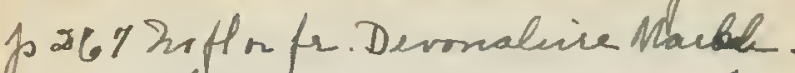
Langeat of $49 / 8 \times \frac{7}{8}$ in. Hence poub btien $v$

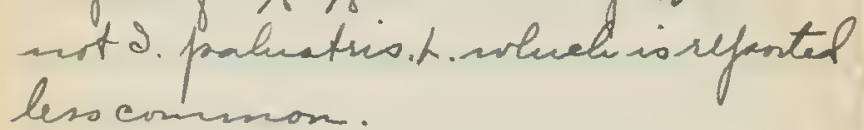

4-1-29 Kyllinga brevifolia, L p47 Fl. Dewnalire Marab bos les

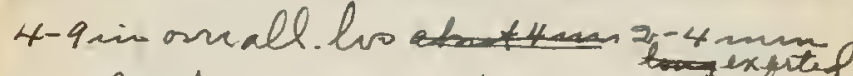
wide. Stamens2, style a cleft The 2 minnte vuter acales lineis. The 3 ef

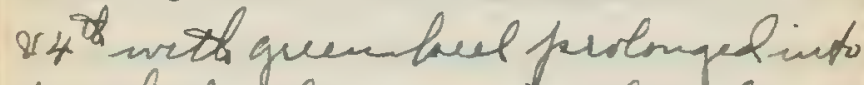
hip. the bos hrasgino hyahis.

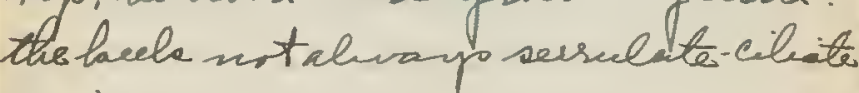
$(20 x)$

4-1-29 $\times 148$ \&

Chapr Rymchroporastifaitata. is 53.This is only pasibility in BFFB hat th all inifestld by thach sment. plantia-17in. Lovasheras 
cuhnoless stommwide

$3 x$.

4-1-29 Pynehroporatiatare, Valel

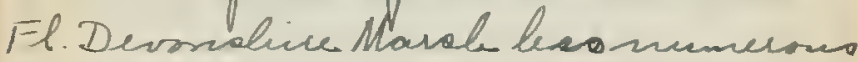
tham abose. p53. Inf filled writs than abos abut 2 mm side the nargins nit really undecte fut the blode bemy tria yulac. Plant 6-9 in tall. 5-13-29 Dermblire Mara $?$

4-1-29 Elevcharia interstiveta, RUS. Dermalire Mavel comenonat inectern enl gesatern pat. Fl(m culem only Tinligh m plant q whichall otter ceclen hal heen euts Fr fin waiono inpupet condition m the phen cacinoto 33 in. herete sefatat in sechimo $1 / 8-1 / 4$ in, thele smetion. taintly viribles motside bat

by no meansasdefinitely as in ill. Culu mot papallose id $\neq$ is tro proje Rinas ensident to truch on to sat (2ox). Thickly dotted math whtedo(sox). Spiladt $1 / 2$ in long. Saales mate, their hyaline mangins narrowatapex bet

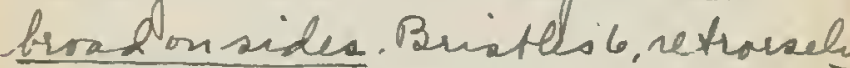
harble alust/2ayain aslongas bedy qachene Tubecle white ratter than black baref, its bane abut I mm wibe while acheure is atsol abot $11 / 2$ man a wileet pait.

4-1-29 Caferiola Dáctylox, Kuntze p 36 Flufe. Denomaire Marah. 4-2-2q Fr. valley way. Beradeat ef $2 \% 4$ mm and all hnir tendancy to invelete mas. ginsesfo. truand afaex. B.Mg C.P. $1 / 6$ 
$4-1-29$ ?? $\times$ \# 1660 f

Farak. p16 Fl. Devonaluic Maveh (notrenembered wheter i.

aballow water. Sof spece clle ted

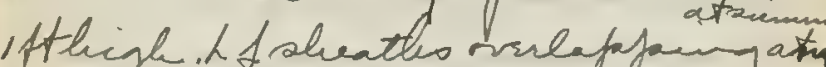
croudef tatte dt * crousder flattercel, lone 2 ffl $3-4 \%$ in, arracence furbich holso hibe a spilat was the

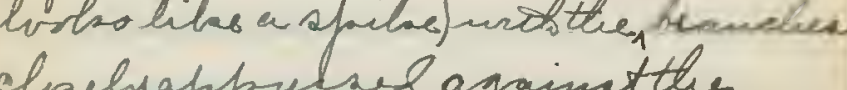
clvelyappulvel apainat the understig the kitangulan on vinged rachis. There baxcher $3 / 8-3 / 4$-is long. the wachis simelarly secundevingel hearing vas shout pedicelel a pilaeleto s. valaprat in 2 rosk. Stilalet

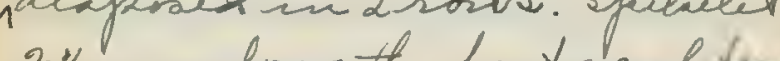

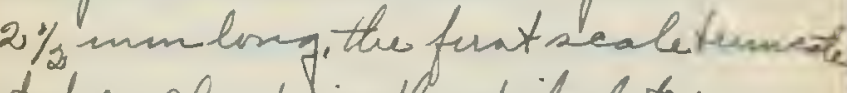
atapax, chapaing the spilaelet, imm long purbturice aobura di haline at ateat 2 green nevnea, the fourts scale funelyridged by lingtudinally. Her ubule plant glabroue ex cept:

higule has ring of fire hais fredicelo firely pelhercent. the sedges of secondany caclis fincly ciliate $(20 \times$ ) and elges g perimbary sachios ho ma os

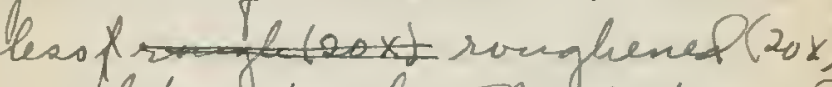
cutof fire teeth. Plack forened.

$$
x \# 160 \text { H. At }
$$

4-1-29 Vicia

Flo young fr. Faat end $p$ Berey Hell R'd

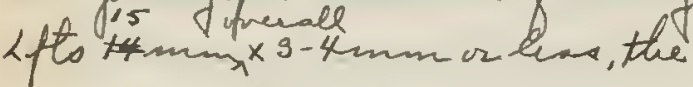
incuersute tijo heng iman, aliate $\checkmark$ seattered hacespongtrit.

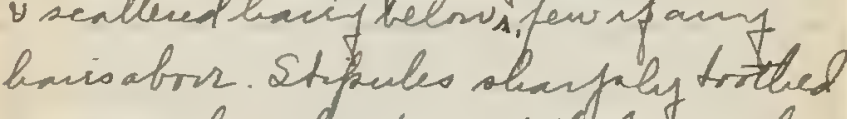
more bes halfsayittate. urcet dack aport in languble. It haing

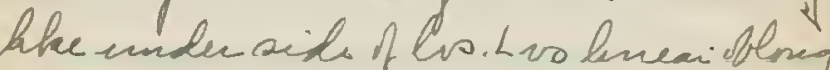
Fl sobitary, axidary, very shost petiucled, $5 / 8$ a mne in lisng. Stand and blue, ingtec trusal center woth whitiale Claw, uring biaght purple, ncalaingalvery 
definite contrastincolor, buel blint tipfeel, purple at afoex hut mostly intide. Ming whitule towardo babe unts a navew lobe almost $1 / 2$ as longas claw on the uppaer edge parjectury towand base. Keel is lesocomprenae? than I voned expect, having the uppered gea folde' squactly minard malvin ja flat surfer 2 mmor mon wile, the whole bing pouch-like. The lover edges gthese plapos are cut s traight aeros to theclaw for atrade chy is twaselymaurining to the dew:

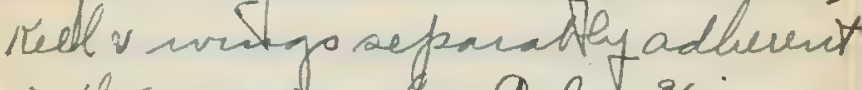
inteis region only. Caly $9 / 8$ in

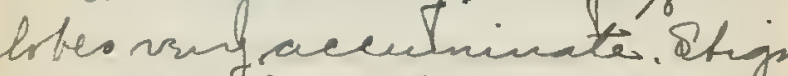
definitely hany h hed on back.

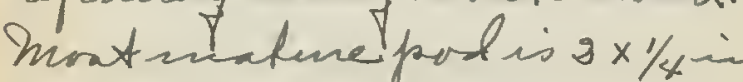
Lno to $1 / 2$ in lnig exclessure 8 the divided teudrel. Plantapuoding

bina arches 6-10 in * 161 \% 4 .H

4-3-29 The patch from which the abre spee tabew had heu deator hut plants notfor wany shorvel some fl. Chan as abos, stme fl he mon parple than the. Planto to $2 / 2$ ft hangest hs $1+i n \times 1 / 1 /$ in some nove or liss bluntatafaex.

4-1-29 Scippus validue Valil p48 Fl. Demalicie Marab. Sealea Lan, yeen vbroum, the lighter pastef dotted brown Elges hyalune v finged. Sheaths at hase oculun redidia broun.

41-29Dielirimena colmata AS. Atelacele p49Deronsice Maral. 


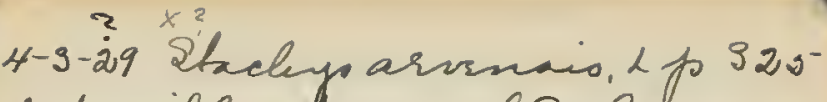
Fle fe. Field eatg wannch Pond. Leens

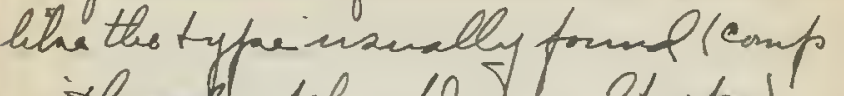
vits a palant? ithaltype) exceptthat $L$ wave $1 / 2, \times 1 / 4$ inate of $? 1$ xim or sualles. The plant haw a lauperatritu, bonden loskmall pacto. Flo. seem just bine sow these iusual type ex eyet that the prller a a are purfele blay ger thene grayiale oneo of the fype and the 2 proterio atanena darsa thich at to 1 filinent on farliapotion is a part anttiens incile the anteriós tamens are une slendu thes sut. Coulyx lobes perleapos sh arly

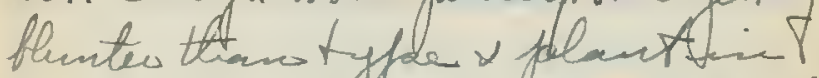
ame cares levbo lichactes das los at hast opproaliney glabroma.

\footnotetext{
$x \quad \# 18184$
}

$4-3-2.9$

Serothulariacear -Bude-only / Mart mumeat sideg Wurvich Prol. Perlipo

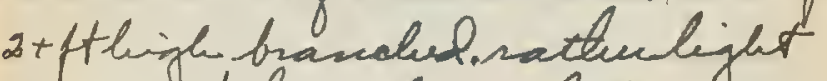

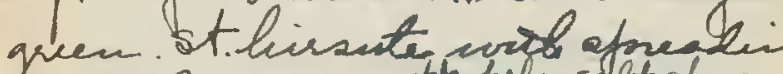
jintel hass. Las ofleng nowne of entire excefat for lin muceonate tip for uppare $\frac{1}{s}$. helow that wott hitsent

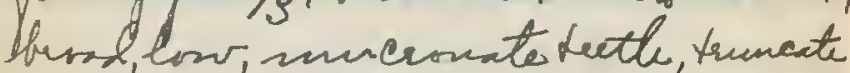
or sub-endate at bare. Lever ho 3 in $x$

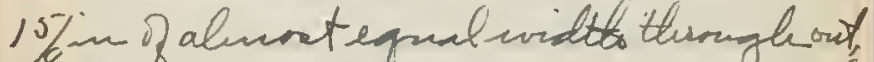

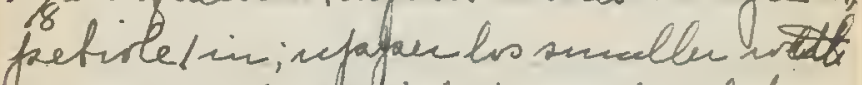

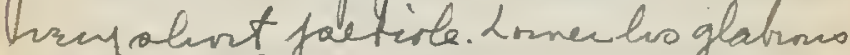
afore wett fointed hair on petioke on ven exp min-sit below, aloo a kew on mingins bpfare (young) ho finely patrenced bot aidea. hav jivlte os some ottum sum Ar be Gland tipajoes. Helo srlit

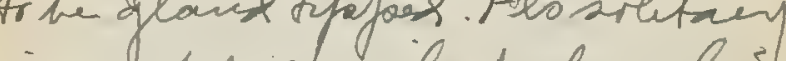
ir ipjeir axila, pedundes attin de ye $3 / 8$ in vinglender. hany libe d. 
Calyx decply divided into 5 hiven lancerlate, thenred lobeshary veluate at at this ato ge smm bu Loveredges globes hyaline s sinute makbing slight ontivand augle. Lotes almat equal, the 2 lover semma a lith shrtes an less t $C$ lla wide. ate. Courlla tube rounded

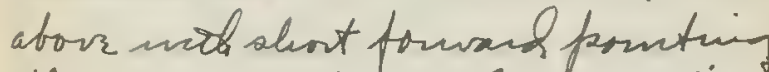
thent aperr beheatte. Pros 2 lyjef? the 2 lobes gthe uppar hp ove rappai the 39 the linver in bud. Lobes, absat

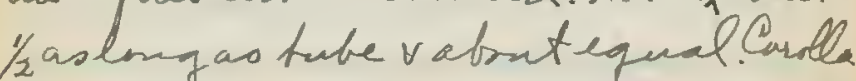
sligetly haing vutaile. Stdmenses m shot filimints attuchel to base o tub. Guttus lange, the baxe 1 cell peach antter alightty tuftel hany. Staminde 1 het. 2 uppou likes of crilla exactly bihe filuments of stamena. Viaing suerios, 2 celled पदि ovalio on axits folacent ae Style olint, atigma pisd cap.

itate. To color execpatguen ivident in corrlla, an thers olijhty purpale tinged. Terhapo Nichsia Elatine $P$

4-3-29 Silanum tuheroum, L fo 33y

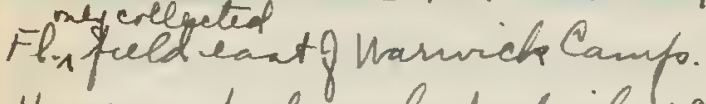
tauson pedincle, judicilo cahyx bhen flattened v jouted. Pedicels. bfiritely jisited 4-9-29 Lefidinmmiginicum, 4 p 146. 2-9-27 than his ill. Stameno often 2. sud to young to determine pasition of cotyledons.

$x$

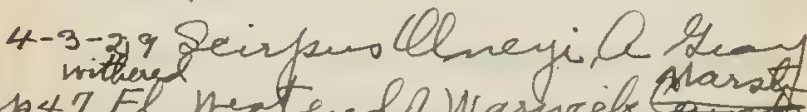
$p+\eta_{1} F l$. Weat enel o Warnick 
$x$

4-3-29 Finbriétylie cactanea, Valel. is 49 withued flo. or dide of Weniele Pond. 2fin B.Fog B it manth this Culne tho not atriety terete ien os definith 3-augled. Inflin long. Lonyenthimpt reral If 2 -4in. Style flattru darthi. stapel haing. enlangelatbase

$x$ ?

4-3-29 Runnex

Fl. Warmich Pond fo 109. Wing o sepal eroce tut only 1 dearing a well dersh. ofoel tar hevele. the otter two he a tuherele very mucle ausaller or armetinco none. hivip condate abrit Smme over all, pelide a towt sume

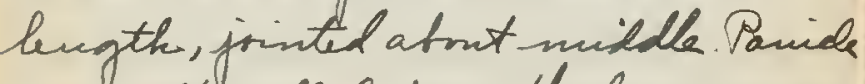
glet callel open the $l$

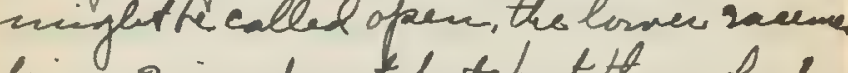
hing 2 inapant tut but thes intuslo on at leat the ippoen racence

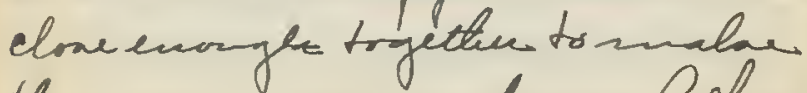

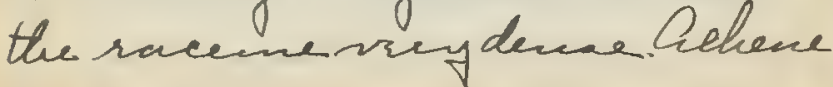

glabsons mot yet ripe. Luty uppen parts plant (16 in) collete \$ this plabmes, the oflony-lancevete hos $4 / 2$ in $x 1$ in craptalle

alent petiole glatuma, of ang plen papallese below, the mib-rit heow 3 rldgel. Pedicilo filipum

x-3-29 Rumex pulelur, 4 fol10

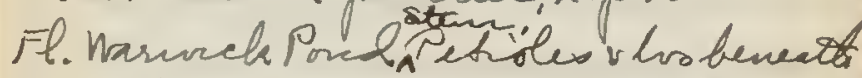
har few shont atipg hair. Bedicel ruy a trut emprast unitators. berently i re pall heava tuherele the

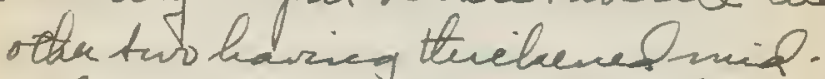
ribourre a be 7 twherele-libe, Whals ray sumch intersupal evento tifro of bustever

3-30-29 Dendroporym wancoile Raf

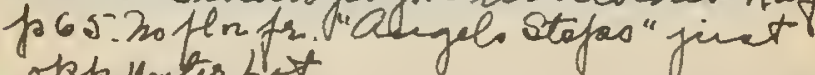
opp. Water Lot. 
3-30-29 Fucies pumila, $<$ fo 102 Fr obeuns l weluryn. Fr 2 in ling pupple.

\$4-1-29 Ficie Lutigunowa, Valal. fo102 Mntros \& Buigataile at to p

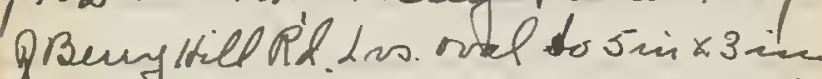
acute, rouled or truneste at bare or shighth subteondate. Veims a-10r pexpintive not wery diatiaiets becoming inuch less soat afoex, Petiobes on ha tush Mrnture 14. on los from Bliglekide $9 / 4$ in

4-3-29 Erythrina Flvumifae fr. Mostrose meat y extrane vorshanging wall into Berey PR. Tree armel. Petioles suif-ribunearmed. ho quite glabrom.

Petioliogonderoulent. blemer (2) at bare 8 lateras ifts evident to e Lateral lefts $2 \times 1 / 2$ in a less the gue be

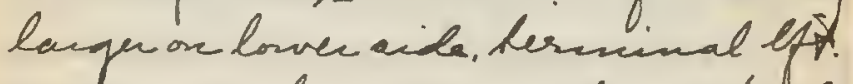
$8 \times 2$ in a langersmetwes box es than long vingatsajetly accu. mincte, afuxblent. il reb scalet dene in ia cence but someting fert Calyx bromich

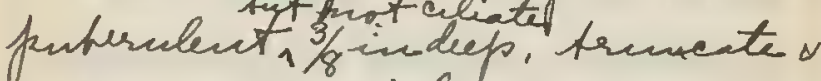
spatting hut with nometives 3 lecto obacurely deseernetle heesw. stantarl $31 / 4$ in ling, sa delle buelup $\times 1 / 2 n 7 / 6$ in wide folded doun midelle. wirgs greeniale $/ 2$ in long, bell alunat aslongie $3 / 8-1 / 16$ in $x 1 / 4$ in beral folded

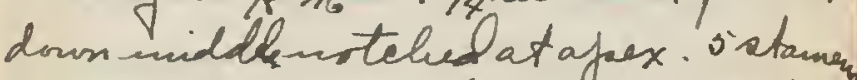
longenthan the other fir. Clang at stipe to bromich puberenturt lilas calyx. style bu densely hain

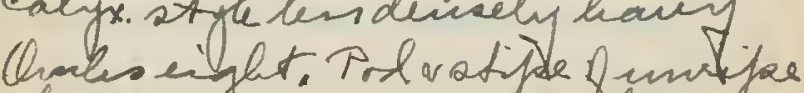
$f_{2}$ bendining morte o les. paterulent. Balyx \& filments 
atill faesictent hit guathy witheud 2n mo case more ttan 2 seeda denlejuel. the otter vonles abote the long beab. Pods oviall sin long, crnoticte f het, seeds. Ifin BM. 2. Cice. this is purt E. capea.

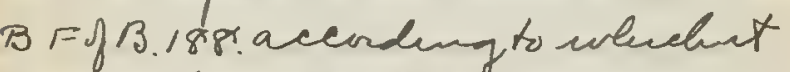
suiglut be E. Carallodendear 18\%8. (N.B.there is a sumall parcess on under

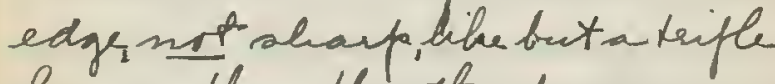
laiger than the othe pracences if any consedere 1 as the obscure heets)

4-3-289 Erytheina

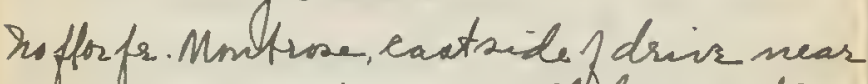

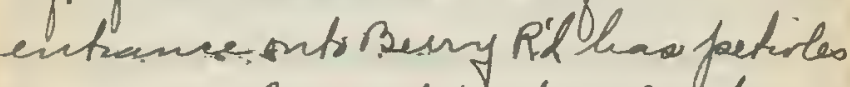
unarmel $v$ not puberuledt.

Lfto qlabrome, lateral one to $91 / 3 \times 1 / 4$ Lerrumal one $3 / 2 \times 25 \%$. Flbudibe atpaksas endent as abors.

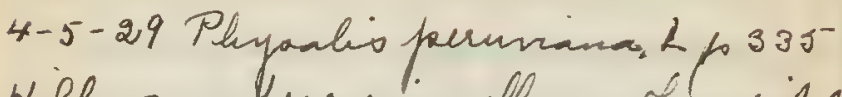

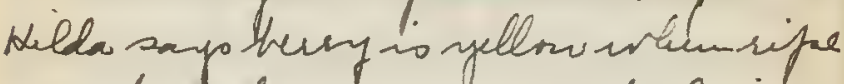
can be datec ranor erobal, called "Hacre Chery." ref-to apee

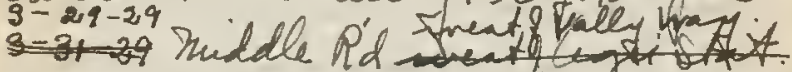
$\checkmark$ oter reentdatex.

3-31-29" Mentha rotendiftha hoflor fe. Moldle P'l no sile jicat enentqugri. Stat.

4-1-29 Menter

no flo fr. Dennalive Maval A. Lrs sugrae pretioles $/ 16$ in pors 11. specata

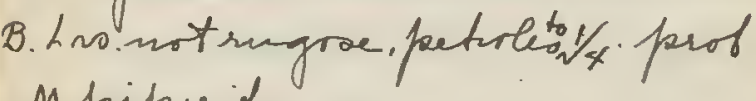
M. piparita 


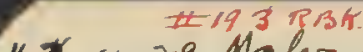

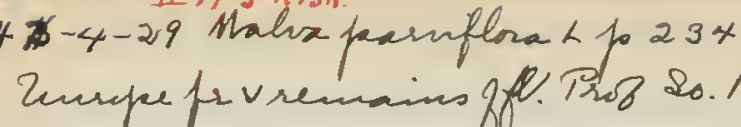
unspe fiv remains qfo. Thos 2o. R' carpels slightly pumbercent. Ed jerg tach vrey dentate hubby.

4-6-29 Anemone

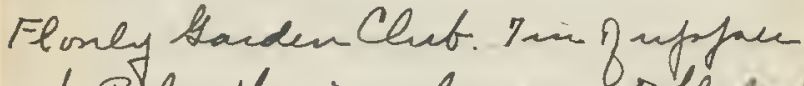

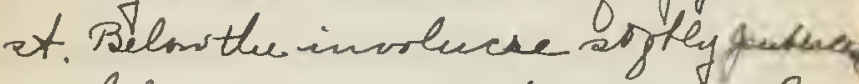
wota hairs somentent appreved or speadeng v sometimes tiratel $v$

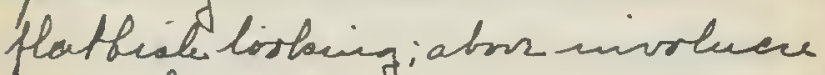
3in the pedende mo have usof appuerab hairs becoming givite hraryat tope. Anrlucue 3 ressile ho, enrequal the langent $13 / 8 \times 1 / 4$ in someurcict of rate in ontline woos a brop base the sbares encirchi the peduncle, Lrospinol divide \& to $1 / 4$ in g base into 3 divisimn thene agaic vayaindinde $P$, aluset glaterous aforer. pubereint below.

Fl 3 in acerss, lavindar purtal the patalvid sefoch, dupen conel upuhesent on back Abluever on hollow ene, pubercent (dencely soatbare) faleate curving upurad

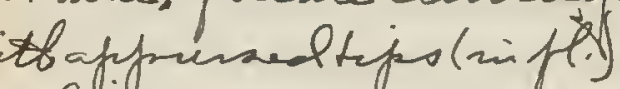

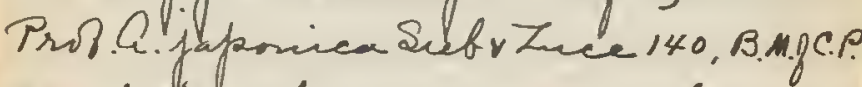
375 but dee hiserefaney in deac. ? ivrlucre s conseder ponsitilet of cremaria $1.4-17-29$ llbmly thign'Ex prib sane as above hancters beve Arob. O. Cormaria.

4-5-29 Aaplenimm heterohionar. thuze. sporee so.Rd. ment g Poinciana Hotel abnct opp. the qraany.

4-5-29 Cariara de Lyma, Biettre p/47 Plv srelldevelofal bit sattrifac fr. Trecencsappean as kerminal hat as atgrono s.om afpen lateral opptile of. Sepade eloged white 
The 2 stamensifilinento wich enlarged barex. Cu each sude of fiment base 2 subulate petale $1 / 2$ man lny basea aleo somcurbat inlanged lorking hle filinesto
gsterite stamens

4-3-29 Zantedeachia acttiopica. Spreng pleo B.M R C.P.138 Fl. Wariveh Pond. Stamens fuee seem to he mostly in grapes 92 butthes vey bar lo determine. llvary sevual oveled hitcan nit hell how many celled Topansile parto

4-3-29 Plantagonajos 2. pos9 Uasinck Posel inuforfe.

4-3-29 Celeriqraverlene, Buttox pars for better dese see B.M.fCP. 565

F. Wrarvick Pond.

4-3-29 Srnchus

Fl. Warivel Pond.

A. S X hasbeen

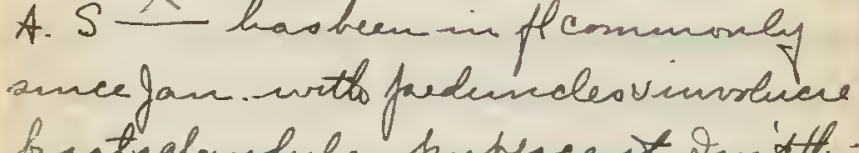
bacts glow he pur pucest. Iantithis Sarvensis? Sue \& S B B.

B.S. notcrming mto fl untillater is thitle-lostong polant Surface ? ho shiming. Duil lif wide varlute eafor m margines factire Lf porickly to touch. 
The ritainers fibinents noto enla frid blues bir each side /

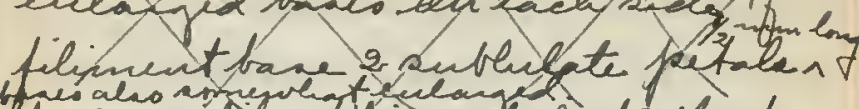
1 torbang tibe fifinentes of sterile starsen 4-5-29 Aleine Balduinini, T. Sundl

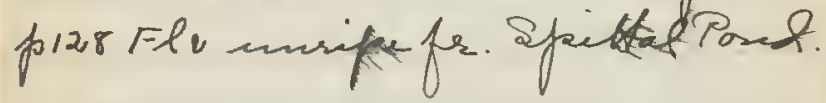

\# 17,64

4-5-29 Tísa maina Bittor p131 Flvfr. Spittal Pond inest end abund. ant. Some falantivasolinit darlequen wotbat: purpalial. Ctthers in fl $21 / 2$ in lightgreen in dense erlosies. In allilower parts are glabrows, the uppier pants: st., hos seypale glandulas puberenct Sepale hyoline on innes marginans- Intme ling. Tetalas fenfole as longas sefpale or aloster. Stanows

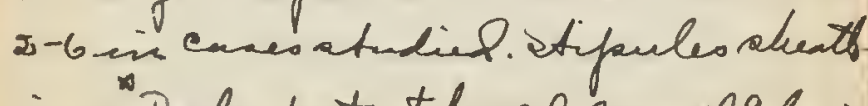
ing Darke post at bere g einus gealyx estes." nacerowat base $q$ factive hit hisergular accemmant het
the los.

4-5'-29 Arenaria le fotidados, hus $\mathrm{Flv}$ fi spittal Tond p136. St wits olurt cousurad pointing white hais. Lroles thichlyever dist similar uperard painting hairo $v(20)$ show lighter dots hemeath vatres. Plant 6 inchigh.

4-5-29 Sagina jarocumbenc, $p$ iso. spittal pond. 1afee oncly fround among the Trina and matima 13/4m high glatem thenghont. Las clapping but withont atjpules. sepalsv atgless 4. Vahrs 4. Sudshers than $12=0$ abizetty reniform n pear shapil flettenel sh me aide

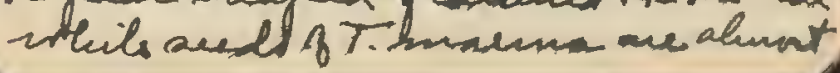


imanlongr neach as beorl bota tubeciulate by but diatinetly different.

4-5-29 Fryttiria

Fl. Tree so.side of So.Pd offo Cotawded no hroon tree. Fl to $2 / 1 / 2$ in lony. Calyx $1 / 2$ in long viry dach red broush, atien. ing thi wits seatteresory aleast appreand hacis. Colyx not taplitting the positiong steetherident, the 2 . poateris ones ving sacure, the lateral

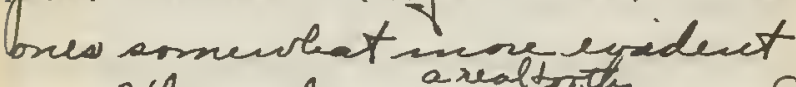
lthe ancterios one stand and adarlar rel than 4-3-29 are lunto

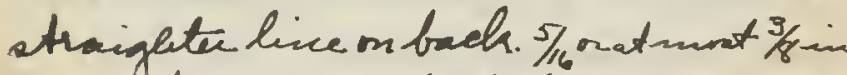
unde frebed down tach (hence nassowes than 4-3-29) Hingo $7 / 16$ in long whitic,

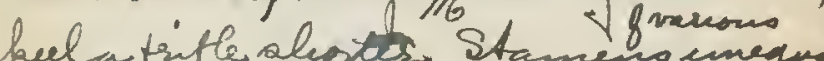
bet ont lenthos (motas $4-9-29$ )

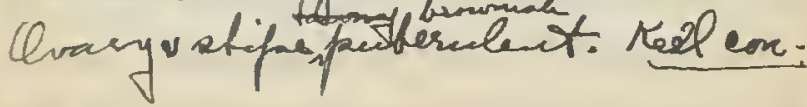
-

iato 72 distinct pestonot at all mited falling for wen the st calyx vatudard are remme? similar to the wengsin shape ve krifle suncller i. - Y/8in long.

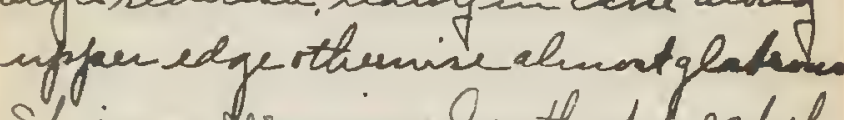
Stima derminal on the tipgatyle

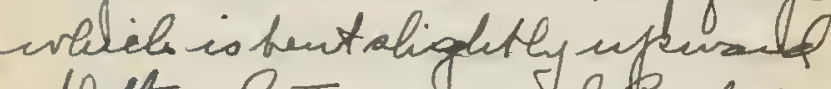
x flottened. Tree drand. Rachiv pedicelobightly parbendent Hedicel $3 / 16$ in is joute in the H.V urtt the rachic, the H falling enily from the pedicel s the predied prons the rackin. Ifin BhgC.P. the is pror. E. Cavalldendeone po 410 but

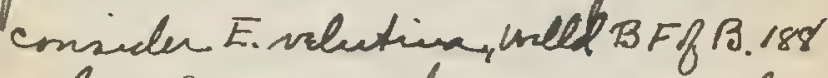
vothers. Comp with 3-25-25 wo wat tree op trus. Thermine Valley Vay.

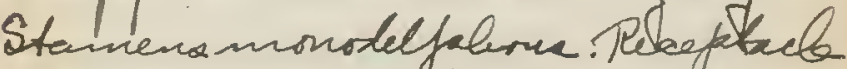

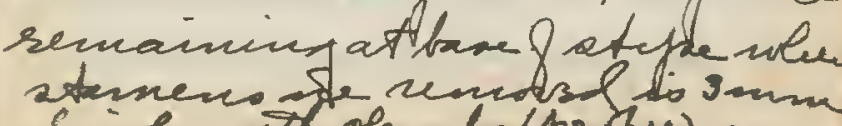
lighe with glanda (profsio) 
crching the base istifpe.

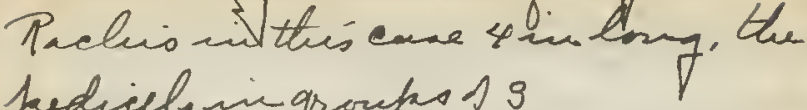
pedielb ingroups of 9

4-5-29 Terminalua Catappa, 10260, BMolC.P. 534. Fl buded viyouny hn the rla ho bavin fallew. Field rastgCander. Young ho. hene atos, rachis, bactor sutride goalyxliter histy diuny.4-iv-29 Fl. Par-la-ville

4-5-29 Solanum nigrum. 2 p836

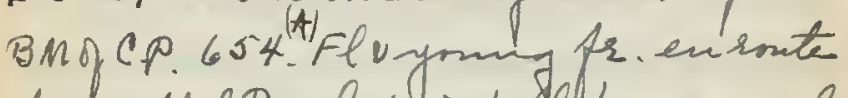
to Sputhal Pond. 6 hin tall! Las coaraly tortud. St purpaleale, pubercilent $P$ not sleart ufuraid curved vpoint. ma hiv. Lv wits sinilar hais on jems hencotha and urod veltired hivis (seem to be 9 printed) abris. Flo not mone thences g/pin acerso

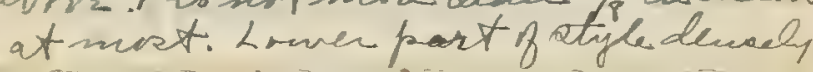
hary. Filiments ary rparalyif at tall haing. Corolla Dofty alits puterulent on viticle. Cpri h. hav thela dot at a peex(B) Bud. En

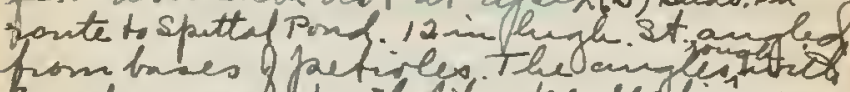
inapecusals torta-libe perfedionse.

4-5i29 Holcus halejaennis L. foll

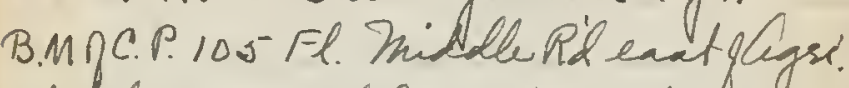
Stat. hmme notb. Condia tree. $11 / 2 \mathrm{Q}_{3 / 4}$ in urite lover ones oftere purple. Nip. rif white y promment abse heeled below, flade niany veinef. Since spebelet are a ricel purple brownan 1 sone of then prominenth

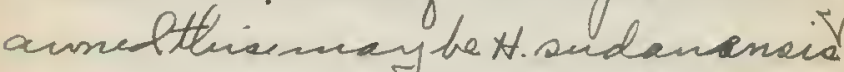
Bailey. Allsedelomer ars silby foubeseat

4-3-29" Polyporgon litaralia smith 1028 Fl. Warvich Pond or pubs. en fieldv ivate place un norob sile of id jwat eact If W. P. Lis 3/8ine(i.e. 4 lighes) Eppen 
sheath inflated. Pavicle bunches at firat apfareses

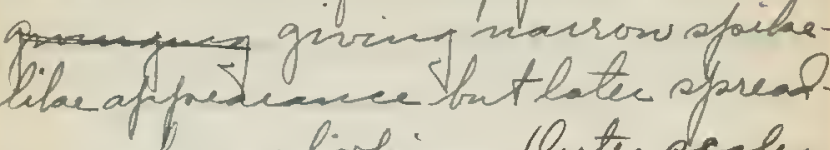
abrit 2 man long with awn as long

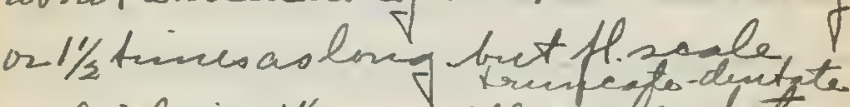
which is 11/2muv veredeat has delicate anon of 2 mansested belon aforx whele suggeato? monspeliensis. Def. Branches I rach at leact tow mextrenitio finely hiapid hairy. Luter seales hairy at leat on beelvedges st. 2 th decumbent at bare, rostin. atnotes. Infl. 11/2 in across uher

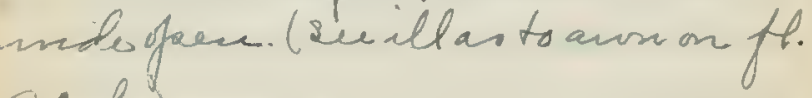
acales.

4-5-29 Ruppia maritina, $L p s$ spittal Pond. Vareonostajeo fim thed to young fir woto a tipes $5 / 1$ in 1 long \& fr alunat $1 / 8$ in long

4-5-29 Nydrecofyle verticillata, Thund. Flv unifae fr. Epitta P Pond.

\section{? ?}

4-5-39 Cublla aritica, Ruban nofln fr. Spittal Pond. Lrowets nareow liepriminathace

3-30-29vlater sisysenchiven Bermutiana L. Common fleptr. Bace getanied

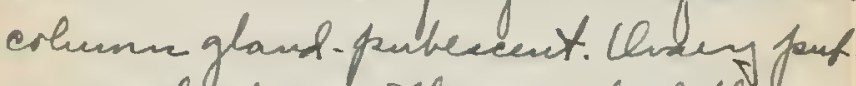
escent $\forall$ periants seg. shglethl so in back. 4-ly-29 a white fi form agit Ex

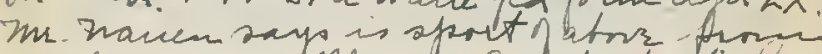
Tuckers Toun. Ceboubed mit studied.

4-5-29 Rrgnasefaena Riutze p184 Fly young pr. fuld eart 9 Canden Prumar veens on lis diatinefly ranad to touch on both arlew 
'unsifa paotis 2 in lng

4-5-29?"Vicia an juatyreie, Pert. Flv of . Fuld lart g Canden. Tipar sut pods deliscing pturiting. Seeds unttef hatid dack ohrsent wist hto virey spola hes of purpalial thek. notalining on pertapop this is V.sativa, L sonde lfto are So $28 \times 10 \mathrm{~mm}$.

4-5-29 Salicarmia

Sesuvium

spittal Pond.

4-6-29 2heris amara, $L$ p15svBMgC.P. 312. Fl at.only with fev poing fr. Hardenclub. Pod laugettans in unbellata, ponts q enciginatis tip blemter y simus mo etrmplete hy filled by the thilar style. sipals vpe talo persict after atamens fall or os pordinatures.

4-6.29" Cynoglesum

Fl.stens 16 in tall from bar lese chot Flv unrigar fr. ho basal hos st. paed. meles, pedciclos oelyx parbercut and niereacinghy havery truand top wath whete hairs mbsty affores ed. St.hosalt. sessile, $91 / 2 \times 3 / 4$ hi. analler tonsen topgetem. Entive. cutt, trumete at bare Sux rit farminent itt 2lateral nuves formitibare comechel witt it unabung covacsely reficulate sepect. Spty parterulent abre below sopth wilte. anfl seappoil racemest muppar $6-12$ in gat. Lover sacenes hulto heasillow

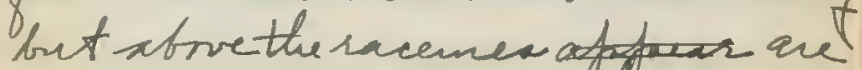
ireapective prosition fllwo.

Thachnes ublud ou beahin 122 
all if-like bracto helow fla. Fls clear blue s/ris wile, hbe fargetmenots in ah pe the seeles thrat the . Pedicel $/ / 8$ in alop lorker parberent, eiliste, sate, nateer bunt tipped. Condla lobeo inahecicate nutlets attechel hybase the searnot reaching to outer id ge, the sucat matime mes on tiese spece 2 man long, $11 / 2$ man uide vnot as high, say rish

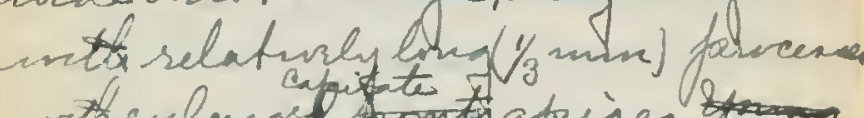

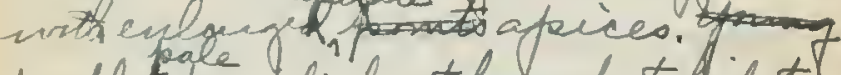
Nutlet ponspliabat bale but dijet preen on to.t. Natin BMDC.P.

Sue 4-17-29" ". fureatum" "Egri'Ex.

$x$

4-6-29 Nymfahaca BMDCP Flmeyo 13 in peduncle form badew chet.lefen Habrot 4 inacins. Petala ${ }^{28}$ hequt the $1021 / 4 \times 1 / 16$ in. Stromeno122 Fillim ta vellow bl to connes ivis blue or therabon

back op promegel into the tifo mateking Joetal. Carpalars fue at bost in Afpbund as to fleaby. yellow hook on vitw riffaer ede Choles numerova, atta cha to walla Petals ellifatic on otbonz. Aluntacede, whitiole at very back. Sepals $2 / 4 x$ in, blue pourfale withic spurpele on edgeswithinit.

Peicupo Cantalia ganzitarsusis, Buter, p130. or N. Capensis varganzerseresis casfo BM.C.T.270. Sue $4-25=29$

4-7-29 Viola odorata L. fo 2449 Flmly firm ines. Achuread.

4-7-29 Linum graudiflorsem, Def p193. Flonly frmemas. Dakneas. Filiments pubereent witt a shent capillow dtaminole tt each aimoo 
vorte pedicelat bareg"ealyx.

4-7-2,9 Eranthe P.Bs.

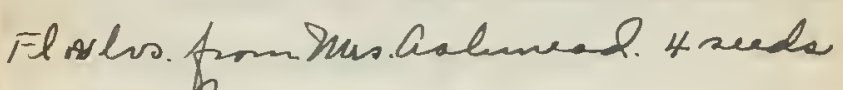
moteid.

4-4-29 Hippeastruen vittatum, Hews. Fl only pichel upaleng turidele P'P. s. Vafintaly divis.

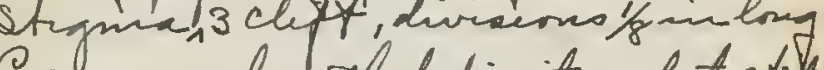
Pir.seq. ned ivof definita whete atape in center and irlite flechingo decure lacenate crouswat therat juat atre pt.ginvestion f filinects 4-9-29 seape form Misis tray. aseabre The 5 fh m fudicels $2 \%-3$ in acining

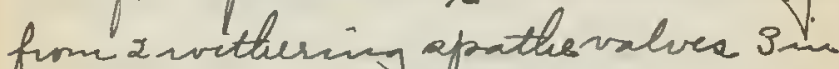
long whra bares Dmpletelyenciele topg padunale. Anony the pedicel are 6 linear bracts $23 / 4$ in br lev. Prob. H. acen 1927 inere gthis apecies.

3. $2 \times$

4-6-29 sparticapaterce, Mulle p 35 . Pout Royal Con to tho fs. Probagras sirce Sheathorar ofuen. Perenial rootatochs creafaing. Larye new roy nel buds an afo peanng at sute rovtselumpo. $2-21 / 2 f+4$ igh stffly upright Culen herete. Sheatto orreappanig vat top $1 / 2$-in from to logeleg iff to ligule onex of Blabe stif, ed jes involute so the th vithin shrt hatives g hule ther appear tucte. shaup printel. Blade iflatterul out at bare is 4 enm wide the uppu(in) sile whitiste, depply ridged. the ed jeshippid wot ift repiras positwing twatle and thind ges mase tichaly linpid Ligule a rung of hairo, turlich

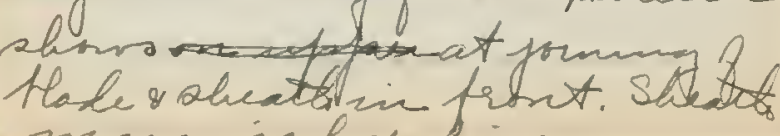
macrains hyaline. 
taros Bladeo in muddle of culm are 12-15in, the ifscer mes shrter to about 7 in sithat apusgall reach appurx. the same are furtturipast to 3 in a pant. Hodes sumilee to three above but immediately becme ahote $3 \mathrm{in}, 1 \% \mathrm{sin}$ Intiltte livert sheath har mly a sleapto print. Otturmine than if ited falabis

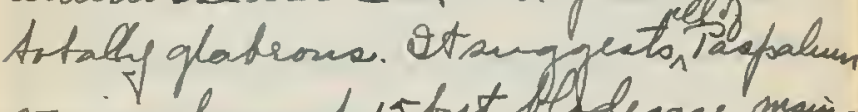
vaginatum 0.15 but Heldesare main lylongerten-6in. Swevin spot in sand east IPR. Cre not noticeith

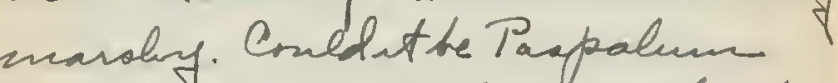
filiforne. Surp 15. Thi folant ust

4-6-29 Pnathirla beioura DC. BMB c.P 30 or water Lot. Fly unrifa for diatinet hylouned tompaned curat Mincana crllected sat erve. nearpostroyal

4-6-29 Cakile lancerbta OE. Selueltz p152. Ippier suel a aceselung, Cover descending

4-6-29 Brassica oleracea L. vai italica Plenek. "Broccoli" Fl. WaturLot.

*-6- 29 Croton foumetatua gace p 207 sflo. 2nadd to 3-celled ovation, in one cace there rvere 4 -cellot in one care ó cello. 
4-6-29. Scacrita Plunieri, Valle fo578 Post Pnjal Cre Fr. Pedundeos pedicls flattered wivts 2 beactibs permp (whichare not detachabla) at bahe g pedicelo vat bare peael fr.

4-11-29 Inonoteraheleva

Souttalando. Petive aheothing fruatrat $1 / 28$ buy of then flat $v$ uringel atrve. Wung rupled, petirce thickens attop. L f at st. ar igles to pactirla. Lf rolled fum one elge to the other in bul

ใ?

4-11-29 Phomix reclinata, gacz sugCP.

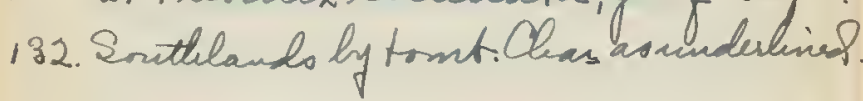

\# 183 N.Y.B.G

4-11-29 Pittrparum un dula tum vent. IA Paget Marse.

4-10-29 inangifera indiear pz21 BMnc.P. 460 Pa-ke-Ville. Fl. PAt Los wath nid-sitidged aton ebures, lateral veino alumatst. Let ureb mid-rit $v$ pardlel to each otter.

4-10-29Viburnem

Fl Bemmehiana La bue bach graks at mo.end. Slerab to stt? Lwo ofep eatipulato, encrgreen, elle patic $4 / \mathrm{s} \times$ $2 \frac{3}{8}$, maxpins shighth werthte entire elc cepat thande tijo where remstely untery low aurate, petion $1 / 4$ in a fatex abulpetly acute, tae acute

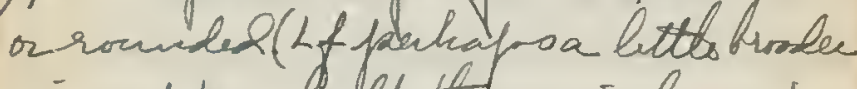

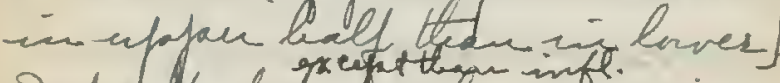

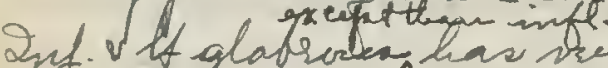

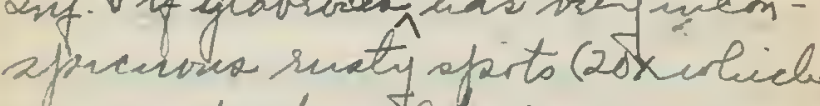
zeray te laresy diro.youmber

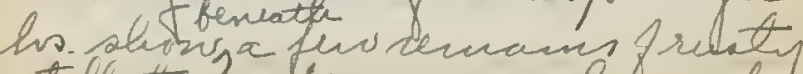

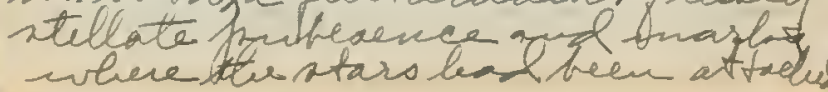


and twew oles bou all hro have punberence (whete in younger

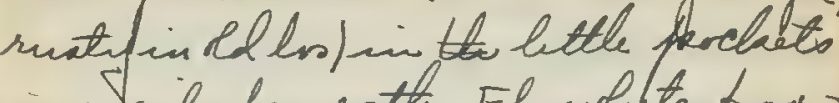
in axilo beneatte. Fl. white, poprani sensile, $1 / 4$ ic acrss. the tube 2 hijle, libes armex above. Ifin BNDCP this is pros. V. odoratisainum, tee p 19 . sunce part cllected are tos glabous fbe no.1-4. But see again frogoungerpart.

4-10-29 Terminalei Catappe

Fl.Par-b.Vills Calyxdecuely velloses inise case libes 6 v stamence 12 .

1 ara bobes $7 v$ atamens 14 . but 5810 aeem therule. "Hent tudian Alunond"labled. no ounles in fl examinel bet fo falleni ponthistre collete learlier in year. $\mathrm{Fl}$ sersile ie in apilats.

*-11-29 Tanlinia

Eivelf crlected sonthlande ts.

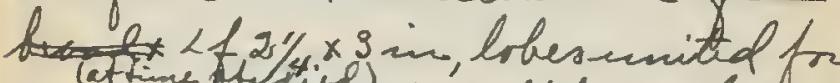

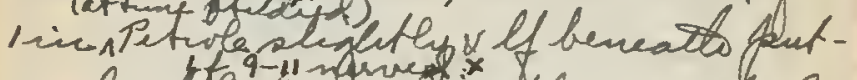

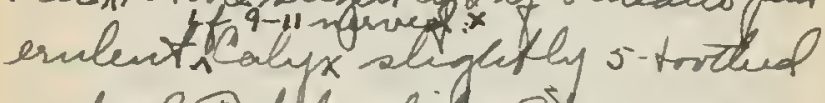
in bing. Petllowlite. Stanens s

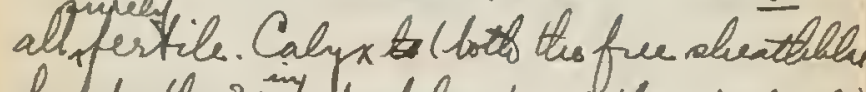
paibuthe $\frac{3}{4}$ istuthe helow (ve is this pedicel?) hears shost stubly brown hack (2ox) re puhars theces shivel be called min tes-cles the pare earity detacleatle orates.2. "Crary atalked haing, its sider thichly crresed wits irlite glandula bras

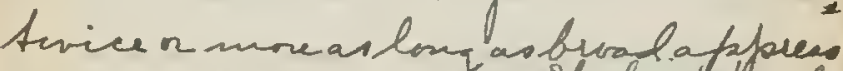
el veasily serafaed $m$ by nce to such

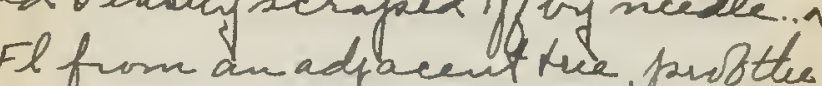
Fl from an adyacent tere pubttee romedesthan otters v shighty premile in center. Statuenots barr delised but seem all to have heer fertile. Filamento uneqgal //8-1/3/8-in $x$ Pefira 1-11/2in thichene at bot ende. 
Banlinia

$\mathrm{Fl}$. fromtuenear Bridge Sonthlands ietala vichid purfole, etrou all veined vreticielated so as to gur funly motted pect $r$ ahodes

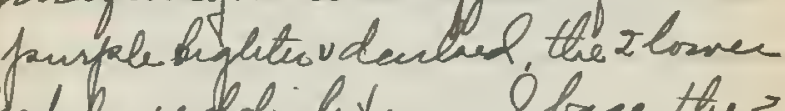
Dletala redelisle torval bace, the 2 lateras pectals whitiale towas bave, the uppau rounder faetal wotb definite large rech erminn spot in center. 3/2rirdiain. Stamens s all sem fertile onny glandular as dese. abrrs. Calyx $\nabla$ pupplial brown. Filments $19 / 8-1 / 3$ in U.B. none g thene a gree witt B. monandse. Kung fo175 no canbedif. ancesche d to any in B.MgC.P 422 unlers poss. B. purpunar on me libely eafo the last to B. variegata. Oll sem aljety fraijents are open inday. Ho fro seen.

* 4-11-29 Lantana Sellowiana, Lankullts po 9/s. BM gC.P. C 31. Southlands $\mathrm{Fl}$ eindenty this tho flhead not welldurlojued. (sec5-9-29)

4-11-29 hantana Camara L. fo 3/4

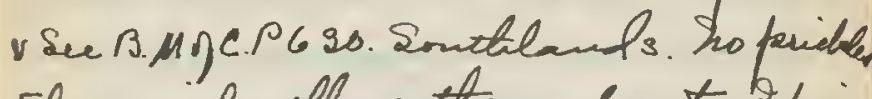
Fls a rich yellow throughout. If in B.M.g C.P. it nunat téte?

4-11-29 Therfairia porpinlnea, Srlaul

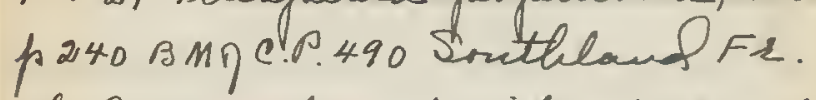
Fhe a capande nof quite rifarex ex des thick yellow sapsiblen cit. s=9-29

4-11-29 Mystur communia 2 jo 2630 BM MC.P.535- Sonthlounds Bud.

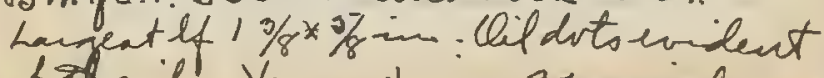

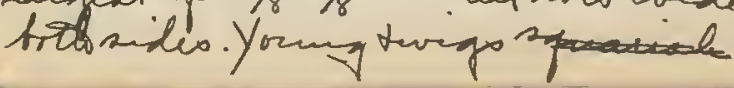


square, puberulent. Peduncle hearsat top 2 hinear bracts 3 mm lnngat thio stageie as longastud. sealyx lober cilcte. Petalas seounting sme rudinentary ones, moner less ciliate, show vildsts plainly. Clvay

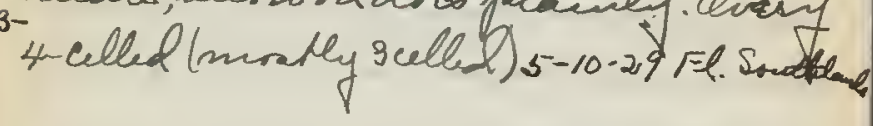

$4-11-29 \times$ (Labled"Dimilla jopaniax" shernt Sonthlands Fr on which what sernstla is farsistent. Trivigs olender reddeab boun puberulent. Kt his in ofp fascieles (pubsinaxilo of fallen hos)

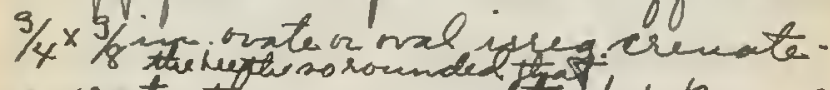

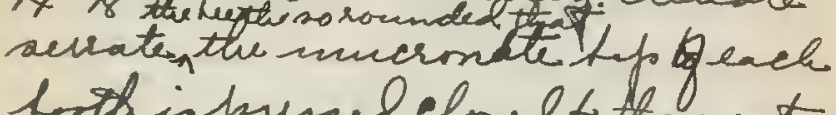
both in puessel elmed to the mest bosth not evident to the truch Opextlent bit mescronat, frane nacrovel ov rounded. if darkgreen above h gleter helow heticulatid venso depresce lation. If shiming even in eary. Fr in shat panicles $9 / 4$ - in jers paxill. ary. Peduncle vpudicel puhesulent. pedincle bacte lat bare, hearing successively. off shont bancher (Imm) whick from theis beacted

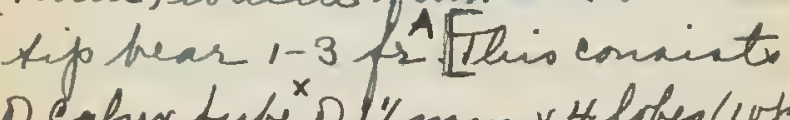

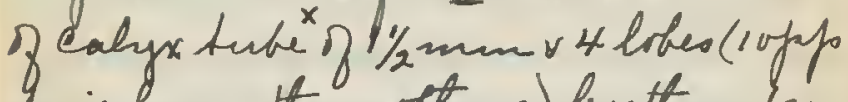
pois langes thane otters) less than inm This man be tabe caly $x$ tuth 8 sersile fla or pecicel if the 4 lebes is the whide of the calyx] seated in the centery there 4 lobes and easily detachathe is what lonks

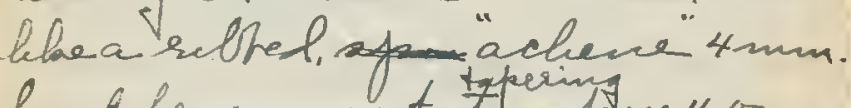
lnighearny at itsing pex 4 on riputally 5 speading oblancerbta is hrvirz a 2-celled tran bearing Aill whettre thege bodes are really fror ivithend vdriel the. hor 
cannot tell whether there thades at topg orary are lode g concla the vary beity ine the conothatur * hence dufuertar to ealyx or whane

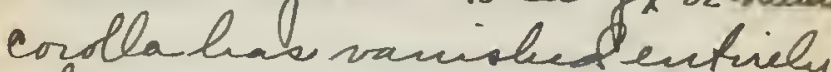
vthere flodesare apjuend jeat isome sast to the fil. Tosigns istamene.

$? \times$

4-11-29 Sahvinia OPfersiana, Nlotgel

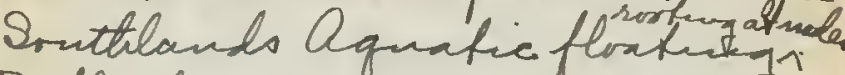
noflen fr Lo opp.alumatravile, $P$ arficular, $7 / 16$ in dian enture, cordet at base enceve ufurand. The uppen side denarly covered und ereet furceraes fot min hijh

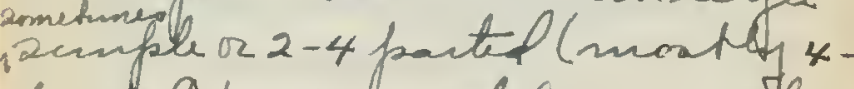
parde d). Lis benesto bing wot

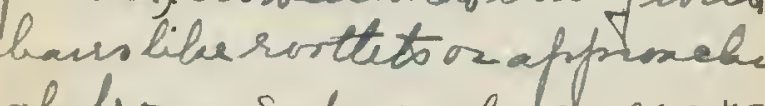
glatrous. see p.4\$8 alos B.MRC.P 79 . dertain bud lelhe fodies on weilat looph

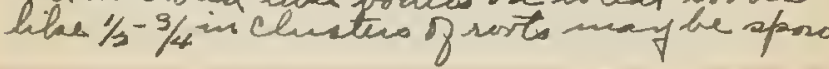

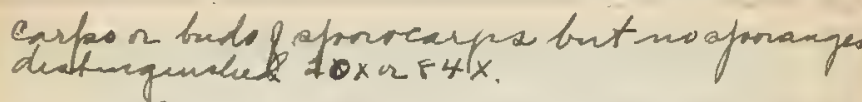

4-11-29 Luilax Bona-nox, Lp 74

SouttilandofFl. Vure st parcbly wit sharfotterms. Lus to $2 / 4$ eng $x 2$ in mide (ttere in hanclues) harbite ter middle lobe 13 in lon 1 thent but wids abaps atumes hifo, sinumes romed Ptuae, lateral lohes roundel,bace fruncate, may jina gef heret wot sharpbut mot at iff spines expon latual lifes. Youngahots deonze thechel wol minute doto gqueen sotthat tho glabrous it linbs perafty

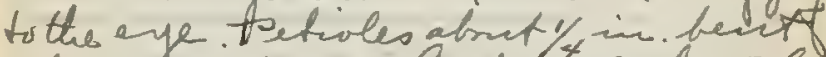

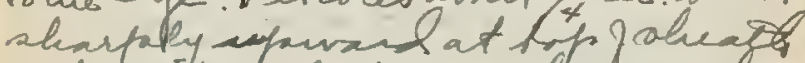
whete keal hil are bisme, the eurvingtutwan $\rho$ again. Pelenceles

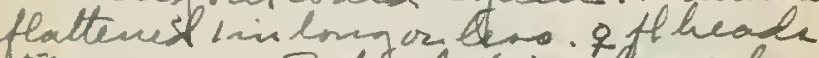

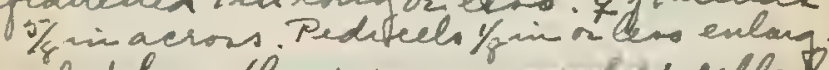
edat bace. Clivary seema oly 1 -celled

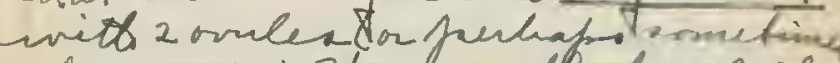

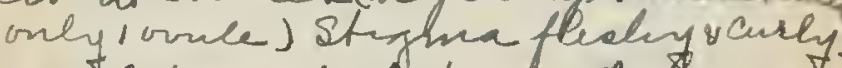

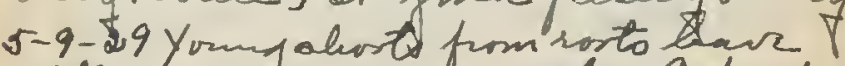

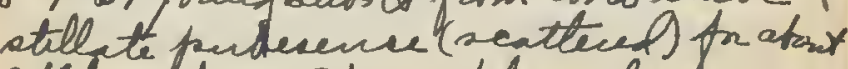

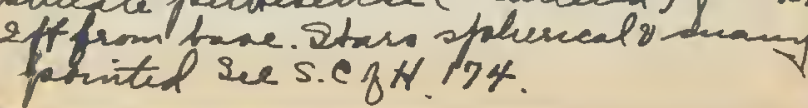


4-10-29 Lageratroz p.258 8 mpc.p 532 " "Uveen f Shrub" laheled Par-la-ville. hastrumb sarroth brusebark at littl libe all-apice but wit nuotetes. [Shrubs obenelgenerally at thiotine are purthergost sew hs vahort the newshroto heise red or 4 -

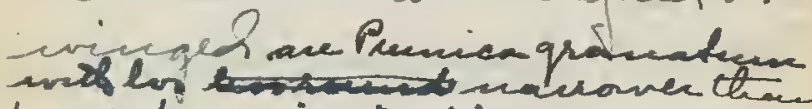
Layeratireminaindiea.

4-10-29 Delfahinimm Ajacish p140rB.Mn C.P 283 Fl fof at Thomis Druy store. Fl pink a whete vrey druthe. The 2 parterion pectale idnited athase wits theis 2 spuns enelned

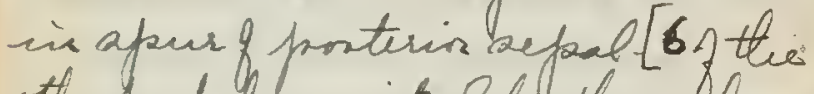
the pretals united hy thir Clawo $\therefore$ to 3 pis $v 15$ peeppetala $]^{x}$ Foliclios 3 jubercent Stamens 1 Dreich 2 har connetive parjicted in white tifo. Stam ban filinento expond l belno

Ethis in care o / fl. reters def. in number it parto] sepall " patalo de ptydrumy Ltrans lone but not beade.

3-31-29 Lilimm hongifloreme, Thent.

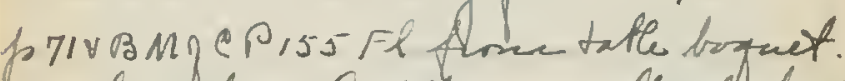
Anthuattrebed at thy mud lle g the back viversatile hut after pollen sacespan the antiu stands ereet the filini tightly clarped bet the tumed bueh anther ralve Filimint boalened oflatteni (yingiarl b bace. Pllenquins oblong adhecive in masces?

4-6-29 Ammi majua Ljo 377 Rd near Prot Royal Cove. Fl. Note each umbellethintinct as me lorba at ffhesh mot as clrae to each the ar to surege as in arme Rubellifuar 
3-30-29 Sclerofiox rugida, Hisit ps 3 Prob meek Nill. Lelue of ill sdere as undecined except that hijule is not shost ( 3 mmoner all ) butis lacerate Rachi fapilalet buabs racily into jints blow each fleret, the flocet carnging the jicit abre it Flnets far enong apant (20 x) as to lork dit firat lide 1 -fed apulveleto

$?$

4-5-29guncus buforime, L. 1068 Spittal orel Dif fundere as dip

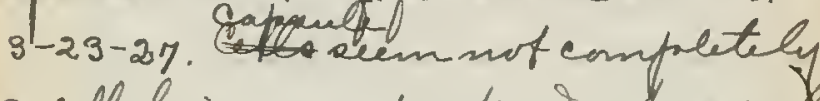
3 -celled in mavpe tr. du fo neace

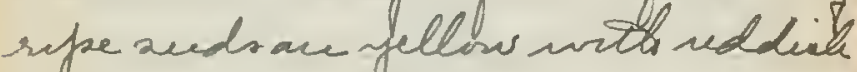
buron at pit fattaclument

4-11-297 amia flusidana DC.p. p 413

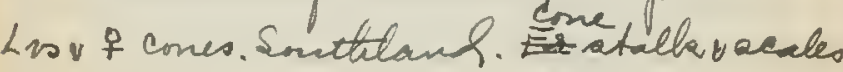

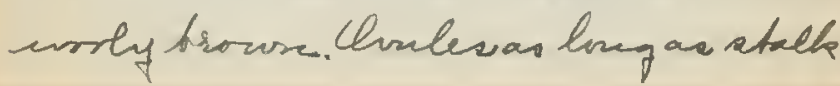
q secale.

4-11-29 Cypirme Paprjens, L p 46

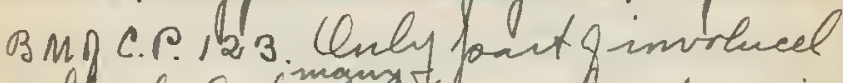
crlected. the falitim tos to 10 in ling and 9-partef to helno middle. inctilf enceradin abeate $11 / 4$ long. This aheats smenth at 4 -anglep itx 2 ali out reath on bas

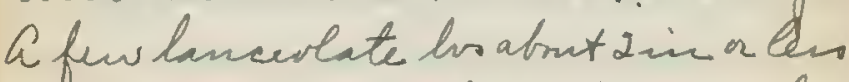
lony sum Sintilands $($ see 5-9-2,9)

$x$

4-11-29 Rajalis flabelliformia L'Ner p of B.M. C.P.127 Southlande

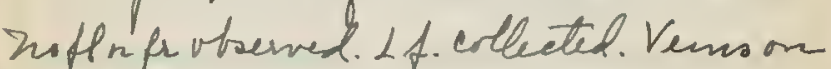
bickg of helow q petirle at tave trans acenffy. 
4-11-29 Cerationia Sifiqua, $L$. Frunsifue p 173 \& B.M M C P. 216. Sosttilonde. (Samear tree so mamed at Agri.stat) Pod $31 / 2$ in werall. At tare a deab-like red ge evciccles ot half way arome, at a fax wret seeno to he remains of alens tos enmpletely foltate stigme folded in to the ilge o pos which beas the seeds. Heen pood \& tivin which hemsit (prob. cadeis of infl.) monen lisminutey puberateit.

4-11-29 Prelinttus major $<1,227$

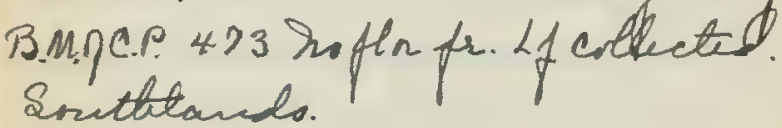

4-11-29 Agave

Fl. Sonthlanda Fl. (mey evitured tropped of fls crllected studied Called ty Hus. Cllan Sunith 3-28-29 Sisal. A that glvo at bare 8 pale have a fuchered lork. Fl paright os strut pole ble ameriean plengt but areende givente on Hight yellsw. Percasts (1//sin tate

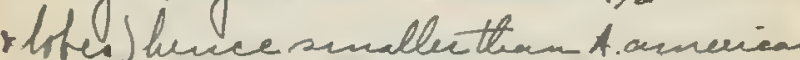

72-26-27. Flver all 23/4in, voraryat this 2 tane $3 / 4 \mathrm{in}$. Style projects $11 / 4$ am beyonf punarit $v 1 / 4$ in manenlesobeyond filimento which are slender terough out. Perianct segments

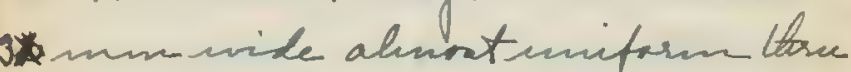
but lengta, much navoree than simuses but brose lecthers filimeits Perbafo the same ap as 3-11-2t Bare grong as at hat fallent rbigies

4-11-29 Pittrparum Tobia at p 162 B.MgC.P397 Sruthlands Buls rocieh

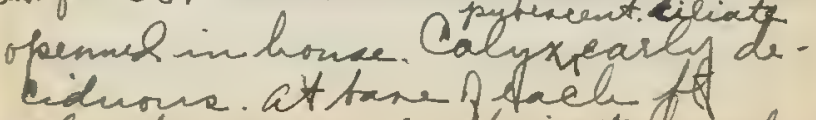
clester nanyimbicatad ovat 


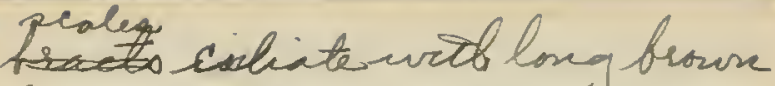
hairs. Infl. rems a vely slest raceme rether than an surbe? Pedicelsolent abnet/sin puberevit Frepuenty woth anall de indures bactat Ance varthe higher up.

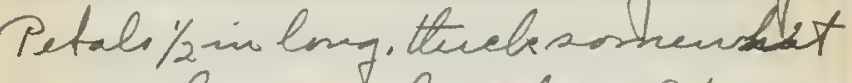
rapgel v crusted on edges. Stamens 3/16 sis, ahnter ltam wary. Chary obtualy 3-angled, pubercent. Trde is tfligh Flontery fiagrant. ag pain or $5=0-29$

4

4-11-29 Pittraphoum Toteia

Lrsonly Soutter lo suggeats the abrir expin bud sa ele cibite wat lon buon hairs. Lasravegete quen (hifiter than ators) v white. Some hro shapel as abrs ottus hes offure komurbatrundulate medve. R this is the varigated Lam Q P.Tobia B.M RC.P. 337 * 5-9-29dsane shrib in fe.

$4-10-29$

ment Indian Plum" lakeled Par-laVille no flo fr. Could ttis be Flacourtia Tamonteli L'Mer jo 248 = F. indica Mer. B.M IC.P S0\%. ? Buncheshar thorno 2-and s-bureler . Lrsalt. on lon shudu bancher witt a atraiget thren $3 / 4$ in lon in each axel Los $91 / 2 x, 3 / 4$ in, alccumenate but noto veny fifthent, baie rounde, aremate? Betirle $1 / 4-9 / 8$ in and the round eftorth mucronate in sin men Lfolabrizerew whe very foum

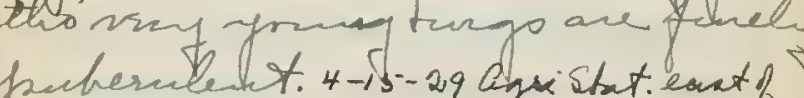
pecherwle pull Pun. $\forall 2-18-29$ same thee Agri. Stat

$$
X
$$

4-11-29 Pennisetume Thupplii, Etend

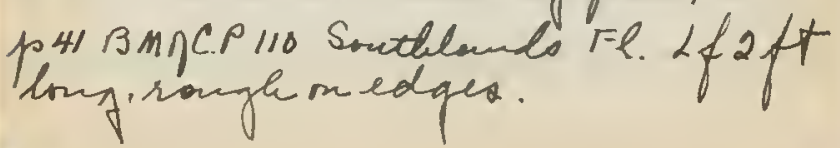


4-11-29 Mannandya Barelayana.

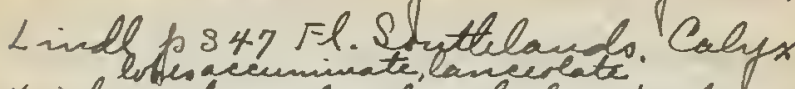
$1 / 2$ in long denrely glan lulan pubereent Corle $1 / 2$ in, breght purple she lighter y to alenrat urbites in thers It

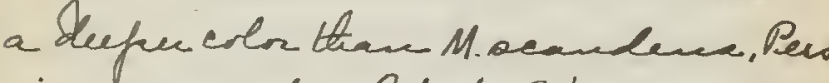
is renumbend to be. Sparsely glaul ular suberent outaide. Filinkuts bon tat pare glandula lleseset esp. fuat abor papulae

esp. fuat abres vagain at tof. Quthers white. Chary wite a feer glowedular hairo. 1 f 2 sinx 13 lidatate codate, muck blaill o M. seandens but pulapp mase. narwavly endate. Foll gerolla

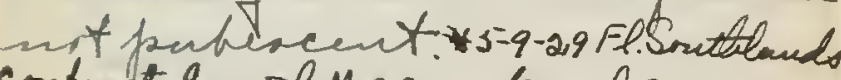
contuatel wrof Mircandeses I sasne place, samedate (sees-9-29)

$x^{3}-3,2-29 ? ? 5$

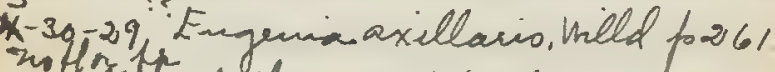

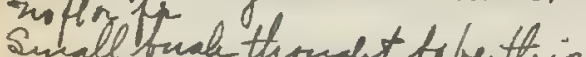
in in side patt be fond Wreck Honarer where it readere shre. Note alos treeson valley way a langeone opy no ail meiv afute and sumate wereres ofy

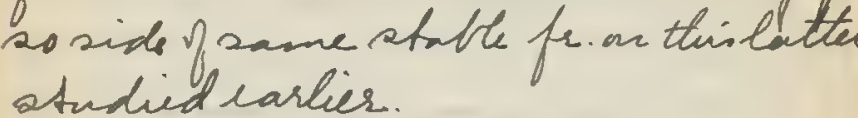

Manch 1929 Ficue puines L. p102 Fr puyple to 2 in ditheluryn. Frat tifo $\forall$ scales budo boualy ervered nots long term silley bates.

\section{$x$}

4-11-29 Hedera Helix, L. p271, BMnCP. 559 Foflor fr. Srittlands a formedeply act unts s palenste div., the latual linkesatgain

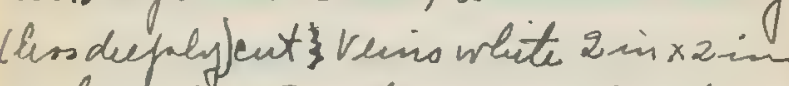

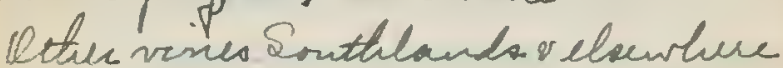
with mo nsual shapael hs none collected wer $2 \%$ in 
4-12-29 Casuarive Cumingliemiang Miq p99. BMycP 2 21. Tree off hedratead har suchers from ronto. LA scales 12-14. Ins. Allaw Ruitt 4-11-29 says the bund ivel suchersio trund ofop Prenste a di at entrance to thingsh and that the inone descrable bing nithout anchers is to be frund at Fairmont and at Prudence Prut saltritts.

4-11-29" Erlaulra guttata, Dm BMg C.P.661 Fr. Sritblanda Fr top

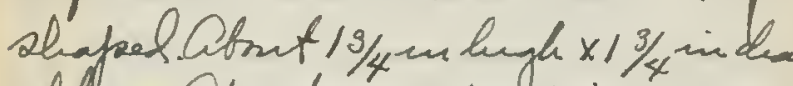

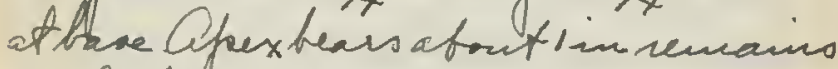
prel atyle. Calyx splet untisurel sea perciatant it flealuy pulpy. Seads inary, frow 6 min lon

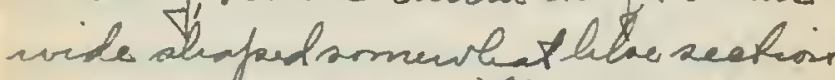
porarege. Rangla insta de p pits the hidgeabtebing nanous tho thy cme ont if lo lowi 20x) furm the ratter. atudeysafo. After satin wipel of orre munt reweots

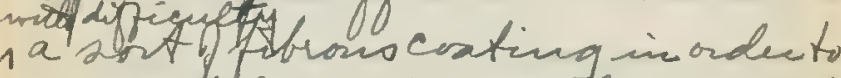
see frittid epeat mot clearly. Note

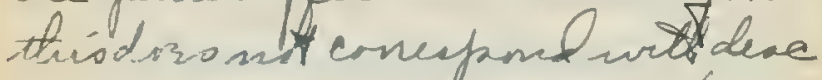
int rineseuns dannes the one tDenry.

F

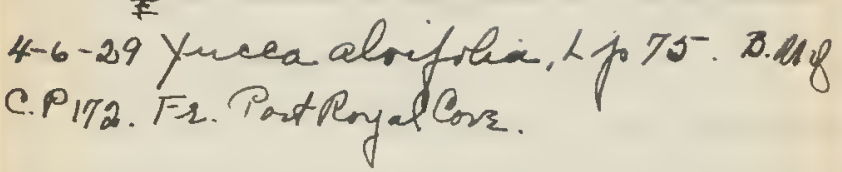

4-10-29 "Laurel" as pue labetat Par-biville Lis alt, elefaticieo oblong. $51 / 2 \times$ in $\times 1 / 2 \mathrm{~m}$ shiningreligreen abovt. Lighterv scraffy below heing crvech wats

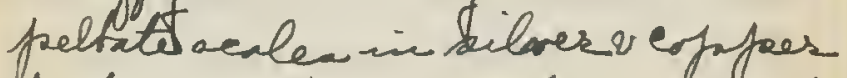
tints. Lfentire, Egually acute at bith ende. Veinsanastor Pet $1 / 2$ in serupfy. 
$x-15=29$ Dhanjiferaindiea, L. 10221 Fl. Agri: Shat ( aolaheled 4-19-27 if coneate rementered valus eanjin 1929 ) but 4-15-29 labeled Avacols Pear Percea anericana. ue Howee Lot leat $g$ Buld Pen. Some if petals tum pinbirle m fading shares a few haves on ufoter side. Stamen 1, style lateral not all lilu Peraea.

4-15-29" Myrciaria cauliflora = baboticaba" labele $P$ C fir statin

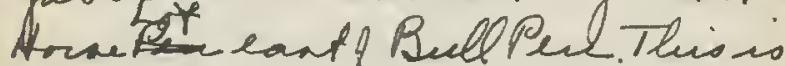
treestudied $2-18-29$ in fr then unow Oal seems as to ef sameas 4-10-29

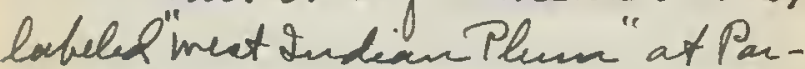
la-ville ex cefat that this (Ogrishat)has nothume, Fr, no th.

Myrciaria canliflora = fafoticata

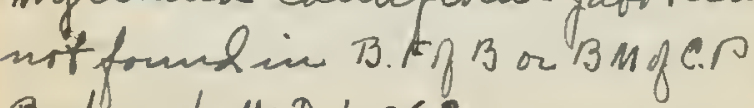
Buther Le MQD.p 263.

This as fan as can be defermune with ont flo. seens to be Flacourtia Panontali, L'Merp 248 = Findica, ver M MPC P. 509. Fr hasa ed lobed ridgearound pat a thelment to jael icel (jurs the diala BMI.CP. V bears veces

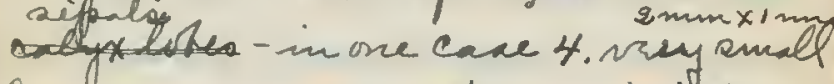
hasuson inside, not exp. cilite.

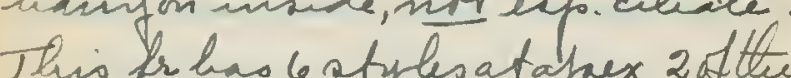
This frens 6 styles a tapax, 2 fftema united at bare. The ving flat seede

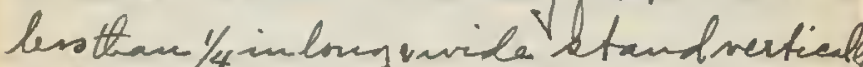
in pulpy fr. Theyarearsingel to mabe 4-6 radis, A or (B) $2 \mathrm{mi}$ ench plane sne abrs the relees. Young turipa (notas youngas 4-10-29) unisutely puberulent and wits conprentur urite buticels. $(\sec 5-4-29)$

$\times$.

4-15-29 Camia Fustula" L p172,3 M/ce 423 lobeled Aqui Stat. Itores Lot wat 9 Bufl Pin by nofince neangate. PAptti: \$ Lf. prenate. Rachir $16 \mathrm{in}$ dong wet

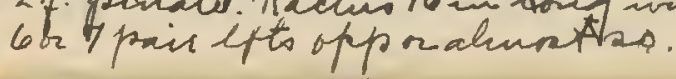


soglands. Petenlayelat base $\theta$ pefiolute $1 / 4$ in, stout wote s asfact as the enlanged base of petirle 4 fto orabe, lover prain $23 / 4 \times 1 / 4$ in, the rect atmet the

entire, sutaceuninate but blunt at apex, ofture or rounded at bare. Blade vatiolute minutely puberulead (notendent to eye or toncle) firm, darkgreen s smenceat leatteer lorks. ing above, liglter helow, the nsony

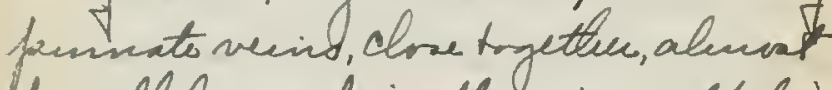
parallel v noticiatle expas eff dries

4-15-29 "Solanum Suy hriifolium" (labeled) G gui. Stat. In palot juat no of Opcedoors. Trumb 2/sindian torsim higle woth many lopping pische binches. Plditatanden atary putercent (hof rusty) erru ta cubrida B corrlla

2t. put, puduncles * Calyx \& reus flos armed wobs sharp. straight yellow apines. L va raternouthine $3 \times 2 / 2$ in deeply firmatifiel vito linea smuate P rupled lobes, the rachisuries Ardla whete 12 blue on same - tilant perhapo paering white turmin they $13 / 4$ indidur. Plav

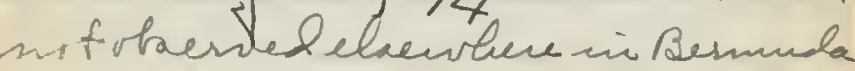

4-15-29 Durayta re faena. L. posis

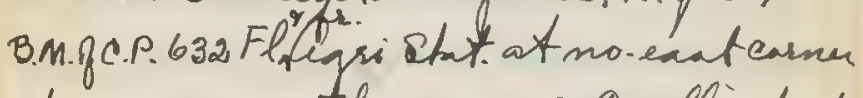
of avenue. Ilas 4-19-29 Courla pub-

$x$

4-15-29 Raphirlepis mblegerumas "tom Su 3-21-29 Shernt labele Chryotalanua pellocarpua " f168. Agri Btatt no of entranter to divelling $F l \%$ \& 
This is not $C$ - pallocayfour if * as acc to B.F.Y B itho flomery dol acere suce Calys in ust didions atyle not singole sud not sugpenbl. Infl terminal racene $2 / 1 / 4=m$, lover pedicels $/ 2$ in, uppor ones nuch shonter or fls ahrist sersile. Peduncle sposhcelostrats, brown puhercent. Pedicel brasted a t bace v vidf i to 9 tracto abor acending tolu tot. Beactsdecidurno(eakily) luncerbete accunnemate, broun, witalose 7 frown hairo-dom cucter intide, and wroly brown ciliate to. urado base thinife ieirs turited $(\xi+x)$ aotheylook I varying diameter Buacto 6-4 mm. In flo no definite div het padicel $v$ hypetteum or calyx tute. Calyx beldial more

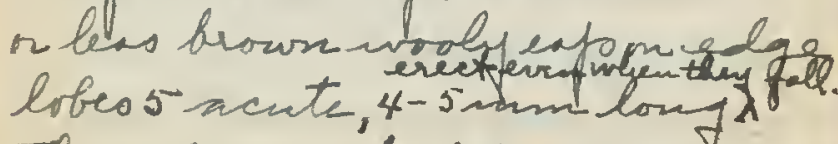
The calyx is the lober vaboux 2 mom

7 Aube de ciduour witt condlas stamend to the halas s white on wett

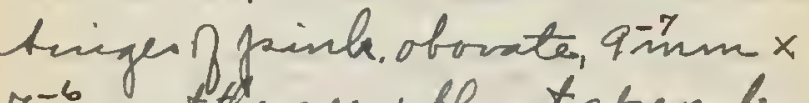
rimm at the veng bluntaferes, brom

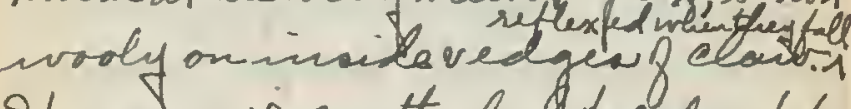
Stannomin-20attached to calystute vdeciduons witf it. Filinents un. equal. red when they fall but white at antheria. Style 9 mm, 2 panted \{ationnt to base, stigmas cafaitate prijectas for an starneme.

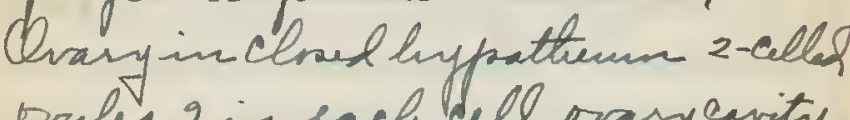
voules 2 in each dell. ovaryeavity when orules sun wrel only a littes under thave hyprathum walle. Style persistallt when tho ottur parto fall tut in upe for is uepresented only by ito bace. Frysin diam, globital uroob flattered a pars heamingumant of otyle. Dark crlnel Wallothic, sul, argending

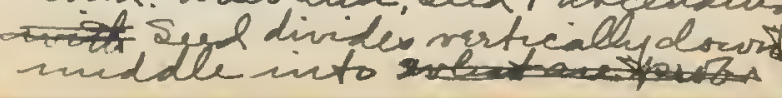




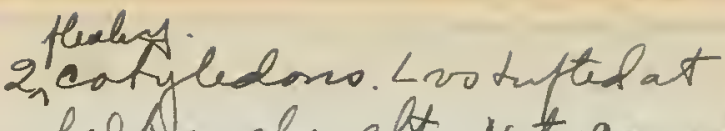

endeg oranches alt. Nont

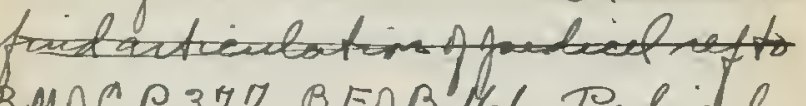

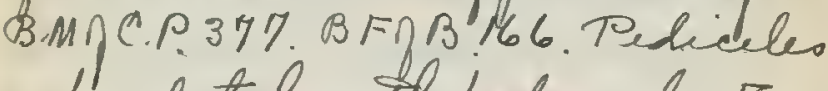
articulated woth peduncle. Fr. wot anticulated on it padicel hot divisisidenturthe dif. dam
eters.

4-15-29? Chelia surata siet u zuce. p 373 (See 4-11-29) Labeled Diervill J Jasnica" This is cance sherstras at Sostenls. If not as dese B. M.PC. P. 739 but fersut is Chelis n Dievillar allied genm. If so the pact ealled calyxture $\checkmark$ shesin A is a pelicelwoth s parted "bactel top and the 4-5-blatere at top f achenelike brty are calyx Crfe crowning ar inferio ovary the carblla being-gon

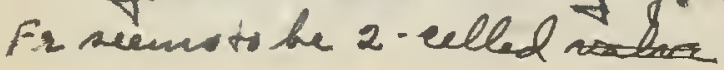

capanter witt arreval tingseeds unalaing falant Pievill a but Lno courelpone to no D. ai B.M.JC.P. ut erm D. jafforica. If hovever Ahelic has suseal ovelex, thio suay be iinle. of whick not'irn one orrule barderclefed asitshosel, hence the disinilasity

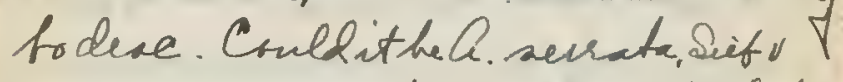
Zuce 10373.? Note Losare quite glatrous. Calyps seg. are mose or leas connate: ie, 5 rep; 4 aep.! i them mare

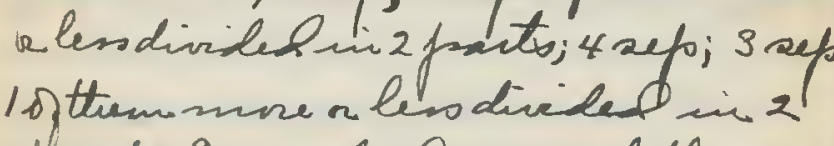
pratto. Envidu A qrandeflna thek B B IC P. 129. 
4-15-29 Emilia flanmea, Cano Fl. Ggi stat. BM M C.P. 782 , hem epeet

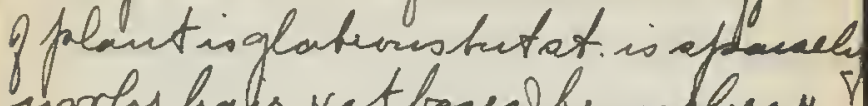
wrly hater vat baces beandlesw manewahoot noticeableysoo. Los glabrons, liveluntate. Pappena

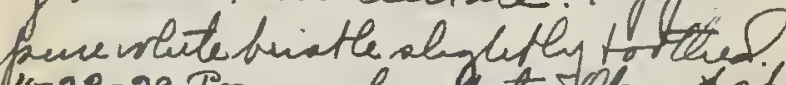
4-23-3g poma bu fatepes nositud theigrelen-yellow of fam

4-15-239 Lobelia Erïnus, L. po 877 , Buper. 746. Fl. Ogri. Shat. bor he by greenchonese sapuilby. Phant lorboglabiner, but thereare sponse straight, white. apreadir haiss on angles got, m edjerghos on ed jear of 2 upjace cor. olla lote Las guemalm, phipole beneatts howe of wate $1 / 2 \times \frac{1}{\mathrm{r}} \mathrm{m}$, ing

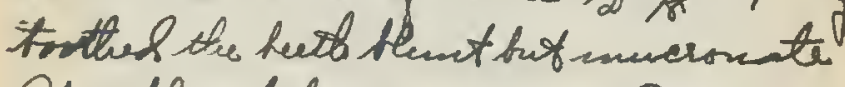
Apest thent, base nassone fto $/ x$ in wing petirk. Apper los lancerbte

or aluontentise. Flompeducles vender sin. Calyx loherongalendecv apreadin $1 / 2-5 / 8$ in, lon gettron. drolla tub irlich is sis, smetines as longas crevela to hes lo lones lobes. corlla clear bhe worda blite center. The 3 lover lihes abut samesize or the muldle me a trifle nacrover, the

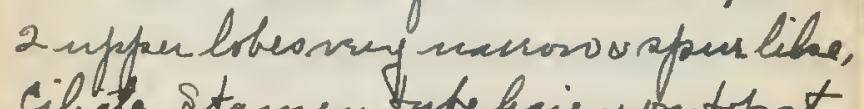
cilite. Stanentuhe hairy on top at back (where it curves formsting allowes) not baing in front hut the 2 dnterion anthers sutt upreijer tuftyluais at tof whic le the othec abteres lonthare. Stinna a pusple cone

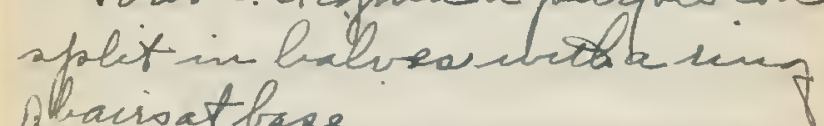
ifhairsat bare. 
4-15-29 Cosmos sulphurens, Car puorvB.M IC.P 769 Fl Ogre Stat in bedw so of divelling. Plant to aftligh the 2 in acrons. Ste pedencle epandy sutride WWalfor but laygen becaune cult. Diffar follow. If $8 / 1 / 4 \times 3 \% / 4$ in, pet $1 / 1 / 4$ in. Fl 2 in unde, outaide thact not eiliat (10x). Petale nots hary on reino $(20 x)$. Dislafls to $10 \mathrm{~mm}$ yellnv, lighter at bare but the 2 mm sthim gular lobes not range until vithing. There bber baingon inside arrund edge I this haing st st wotied 3-18-29. Ouctidero to 3 mum an 3-18-29 - Filinento bairyas 3-18-29. Pollen ar 3-8-29. Cichener fun fl atudid none rifae) lihe 3-18-29. 5-43-29 home mse.

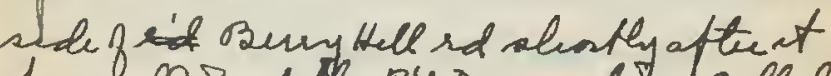

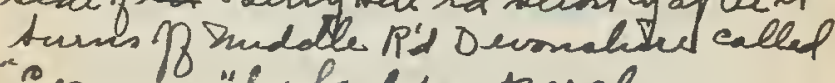
"escurso"ly ladyouprech.

X"schizanthins thyouihs "latiles 4-17-29 Solizanthur pinnater, Tuzupar: BM gCP 668. . gri. Ex. labele "S. leypridere." Filimento foutescent at tase the staminode het the 2 fertile stamenas in center os clestes concars bhe gunder lif. Mndes lorlanotlés seeds moned he rugrae. Corlla tute is shotes thane calyx vatamens are exerted ie ahmot a longas midelle bbe glover lifo as deac. Notealas that idle bobe q loner lef is $20+4$ motichel the lengobs inpturnel tip

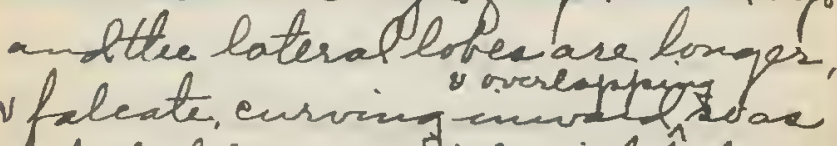
vfaleate, envin petal with hole in eenter. upper lifo varnoin ly lobed veleft ectur s lored the nuld ale one shglety notehes the rttur more lemdeiply claft or 3 lohed the upper an algin 3 lbed the 2lewer defolf clett.

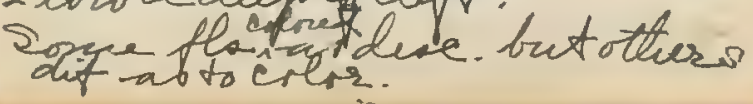


Thento noticeathifairy evento alifixlyso on cofolla

Fl frut with yellow reoteh

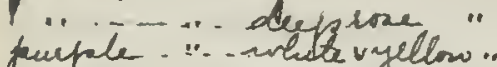
whicte... nerylight."

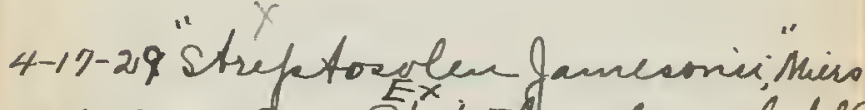
13 MICP.668 Q gri. Fl ad dere labelel

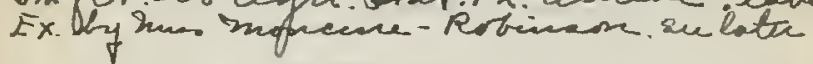

$1 x$

4-17-29 "Collinsia biche" Benet labele?

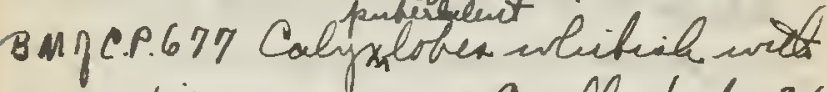

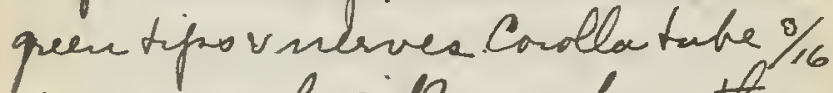
in spuncly gillowe above the uppole liforecture $P(i$. erect) squarion a granely zelett metine pale lavender 1 . Lovec lifo strbel, th with a wall upperarl pertreding folla ex -

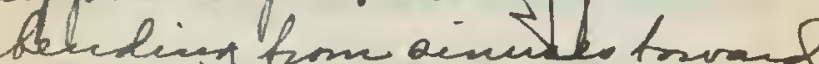
bara. Then foles mut so that thancidéde lofe which enclosea

the stamens lorbs lilas a beel.

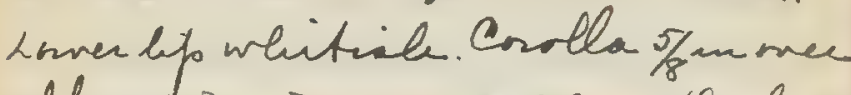
all. Ex ty mis moncuse-Rotinion Coveles

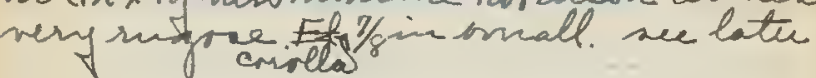

4-17-29 "Anomathera cruenta" lobeled Fl. Agsi $E X$. L Lafairousia cruenta, Babu BMgl.P.199. Crellela tute 1/4 in long Ff. Scaslet $11 / 4$ en brad, 3 lofishaint donhuspot d Shyle hancies suy definite if tifid

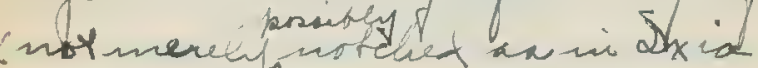
9-26-29) Lint alunat reqular o lober flativinelf separated staing et tedt. Ex.by Mr. H.C.Cdance of Pringfield" Paget. (suelates)

$x$

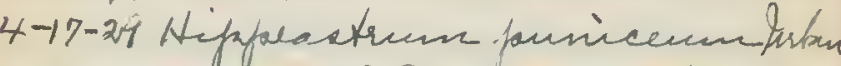

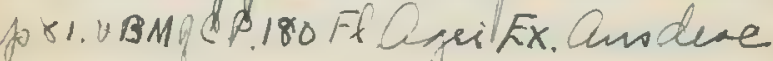

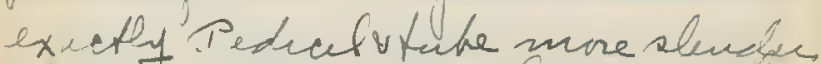

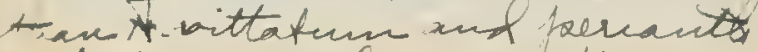

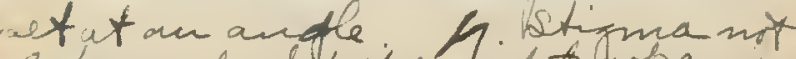

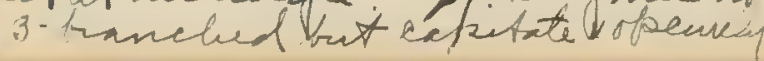


3-lobel Per. salum ind, ligleteched

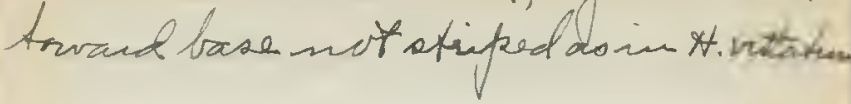

4-18-29" "Sladavlus Bemuda native" ins.dere? H.gandavensis B.MpP

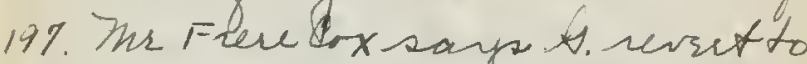
tistormin Bennda. Aji Ex. This frequently oburned at mis. Sunftes, smis

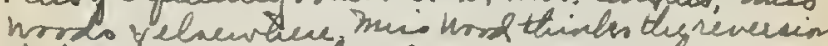
takes place wotho st means g seed.

4-17-29 Linum grandeflerume." Deof labeled Agri. Ex Larh sileportat base prach red petat unahes difinite

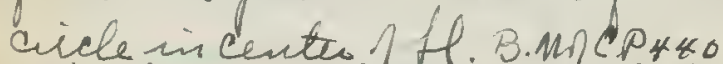

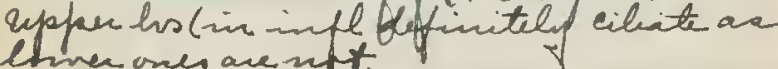

4-17-39 "Trackmmene" Ábeled Ágei Ex = T. Caerukea, P thahan B.M PCP 362 Lnsuggent ion in jencenal ahefoe. st. ho imol tracts.

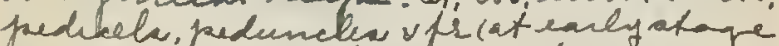
gland-pirtereent. Fre rave brown in early atare, Hattered radially with fl lead s viry lffective.

4-17-29 "Verbena erinvides "sabled igri Ex. Ff Tall slender. Lnon st. sessile, deeply tipinnatifiel into nanowy fineas $\operatorname{seg}$ ( 1 to elmation sfritas the part in Af. glofular. Tuiple wot white at turat, Stamens jint visible in turat. Mrella tute almat ateaight Fen mon part? fl at. 1/4tin apat.

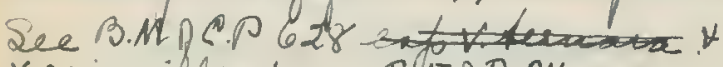
V.erinvider, Lam $B / F=$ F. 311

4-17-29 Verhena bona-reusid jos" in mild fl colleationa Lamotrat.

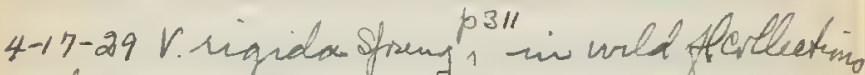
vithervice dh not atud. 4-22-29 wrollem "Verbena venosa" hy misurros. 
n $X$

4-17-29 Nehichryoun beacteatum

uner. labeled Bun C.P986

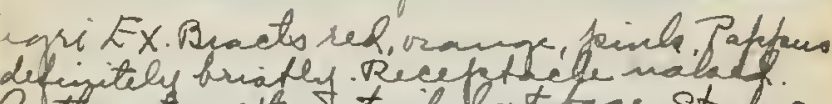
Antrew ongtten taile of tace. Stabos has some lest nilloy white hairs a rnell

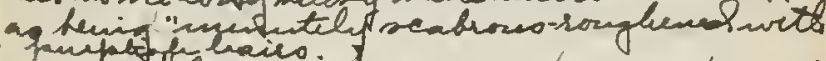

4-17-29 "Cynvisoum fuseatun caleled Fl. Un Fx Ra aheld Flumally not heacted ix sust in axils of the ho whreh are on on st. ammg the sacermes Calyx bites spreading sothat ynurg sed are early visite. Ff. insty clear the. Lis arftto touch (sulater)

4-17-29 "Anchura Cajousis" lateled Fl. AriEx tod Raceme mottalnay in axilon ho. Calyx bres clsed $x$ sdvellimg around yoh ir. Fl dark blue sict white dettuat Lservith to touch. But buls notred in fl red mangined andere BAnCP629 see of this is C. Pficinatis $L$ or

poss a myostideflna. (sue later) $x^{\prime \prime}$

4-17-29 "Hodefiagrandeflora" Lindl labled. Fl. Gori Ex Fin diam Petalo mosty fight rove het sides base alinost white, the coloro Heaker togettre in besken lines BMigC.P552 sulater 4-17-29 "Clarbia" labeled Fi. Osi EX. Qb nof atud. See B.MOCP. s49 Petalo

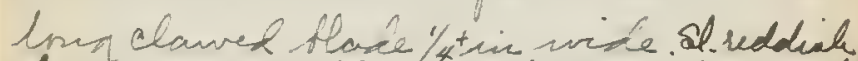

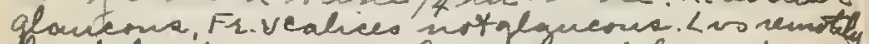
dentate $F$. rosecolore An thers 3 ling atures

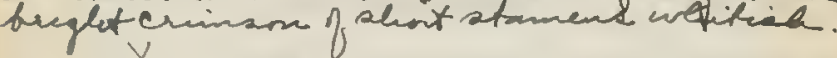
4-17-29" Clenotura Riemnia" Caheled Fl. Arifx Camnothe this becaure ths rse white. Cruld this be le specisa BMDCP $557 \%$ BFIB. 269 a pass Ce hexraptua? Prob. De spuciora Nutt. 
$X$ "

4-17-29 "Silia" labeles FX. Agsi Ex Q. Pro. E. Cafaitata, Dough BMRe P.616. St.xpeduncle pubercent

4-17-29 "Laviatara trimentirs"labeled

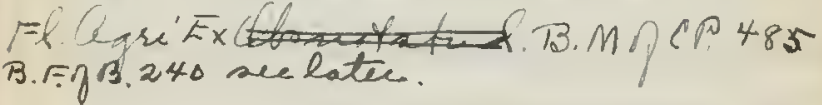

a $x$

4-19-29" Evchroholgiä cariforfinica, Clam bheled Fl. ArsiEx. Bagep 300 Crlon valions:

'enon yellow wot ra ange bare rech alunotrange

crean almostroble

red witt crean bxerevein receptacle farms sance-lebe torder around piril.

(suelater)

4-17-29" Lamólefie Tageter"DC. Ff A7ri Ex (A) B C.P. 781 later Ex by mino moncuse-rerbicusom.

"17-29" Auctopis grandis" lateled Fl. Ciqui Ex Q. atoedchadifinationg BMPCP.PYY reclates

4-17-24"Centaurea moseluta." labele t? Fl. Isei Ex. Felsyellow.

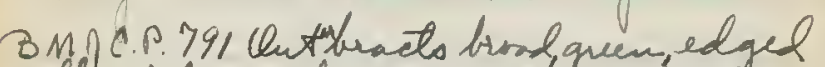

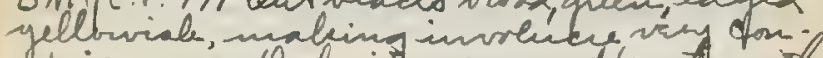

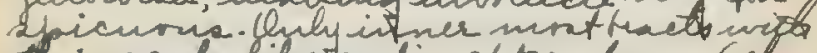

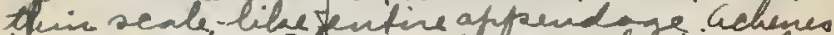

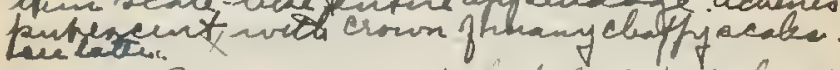
4-17-2y Peperoma "iaheled petpant

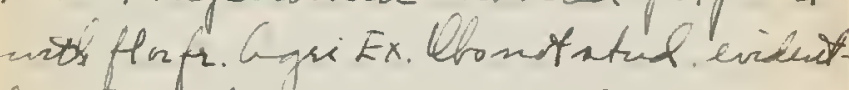
hP. Sanderai C.PC. BMIC.P.223.

$x$

4-17-29" Calodium" Larelel prot palant

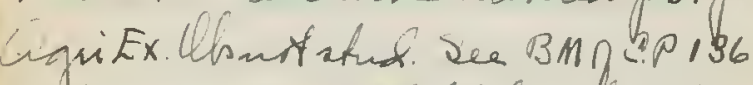
Pit. purfale motted helow, hiqhter above, nevereallygreen. Lf. A Znofanes th Calla- lilar, tube surlen belms. Hak constrietes, then kint. 
4-17-29" "locenia" labeled pat folant Gavi Ex lllo not atud. See BMil CP/3 Lrogreen (darke bronzy at fursts gray grem lates) abors unte veino mike, raired above if purfole helow

$x$

4-17-29" Clany (fourfole tipfort)" we S. Selarea d. B.M C.PGS9 FC Cugr

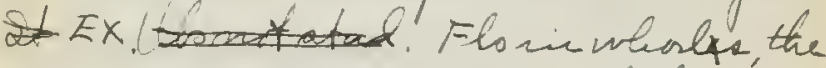
upher lip acked purpole, the losver ligliter. Top o mpl wit la yepurtale ovate veny heacteas ferat lla tht no fls otrived in then axils. Lrs rugore. seelater.

$x$

4-17-29 Zantederelic Elliottiana, Engler BMIC.P138 Fl. Ogui Ex. lh not atudied. $4-14-29$ rudlund lls.

spato m los. Hanalucent.

$x$

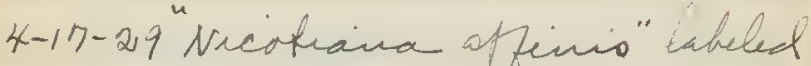
Fl Agri Ex Uf not stuft. B M I C.P.663-4 but flo in many shodes gind as well as white

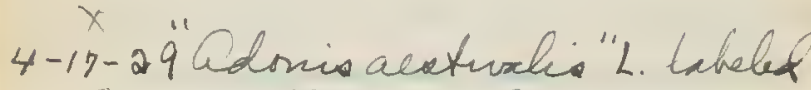
F.C. Exi very leafy Fr. hea lelorgates th at least in

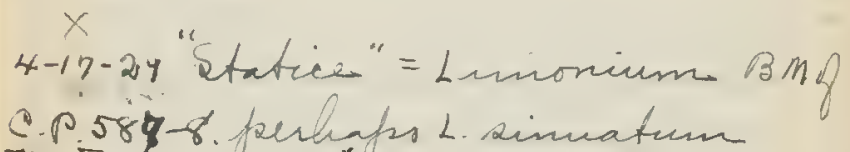
ims. Thanen-say"s. simata".

$4-17-29<$ ufainua sue BMPC.P 407

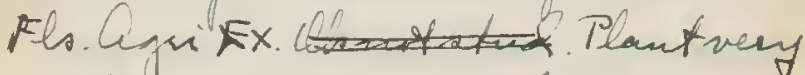
white wairy. Fls ustarkale except

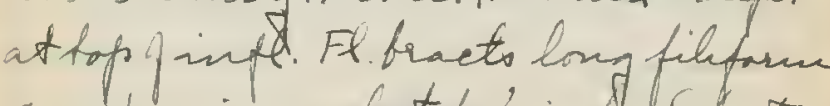

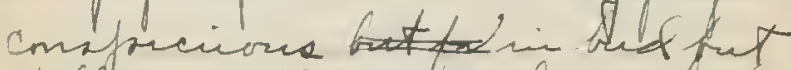
faldirg as H ipara. Flsin shedeo preneb whote. Lue form si the 


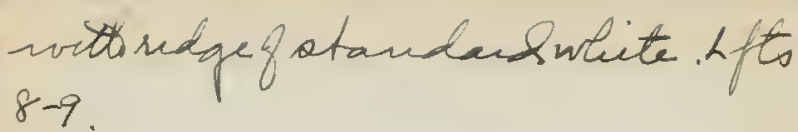

4-17-29 "Alfainia specuosa," selumed BMICP. 204. BFof B. 87 Fl. Ggi Ex The alull-lihe put ip purduce ly a bragt turkel enclvaria Pl vanotur bacteucloseing H. Lvary foubercent, one. celled, ruany ontes on 3 parietal placentar.

4-17-29 Lafecirnisia Cruenta, Baber (nee earliar) BM IC. 199. Sudoalurst stherical into appoudage of a fuominent irluter rege mone side (isthio a caruncle?:) seel brumich at a rattrer advanced stage. Lv8 813 im lized 0

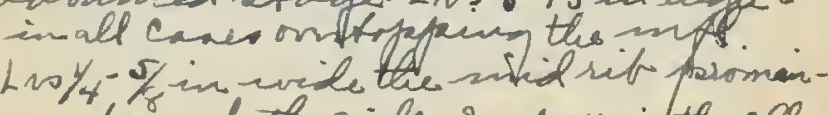
ent on both sides. Reds 4 in the elle

4-15-29 Migehia punnata, DC p 35-3. Fl. A gri.Stat. Fallew ho. flu vbudg cellected Truink smonts, quay brown. Livaspinnate, wholed in 3\%. on vecasinealy aimple hro issune fromstern. Ifts tor 9. the laterafones opp. aluvat reasile. the Lerminal me sactirled. Lfts sllmy to $53 / 4 \times 17 / 8$ in, somenreat falcate tice mis-rit ofter mainelly 8

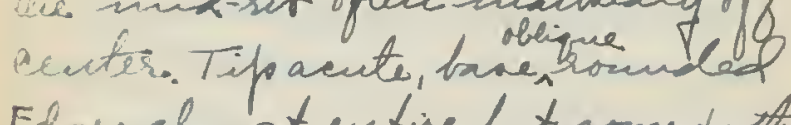
Edge alenvat entire but some torthed sfto vere seen on Fre. Peluncle furdant beaning racence of of flo $(2-6)$ woth pe dicels cumed iffo. a fl. sturalo upright Calyx tin hijh Lubular, farsto - lohel. Conella

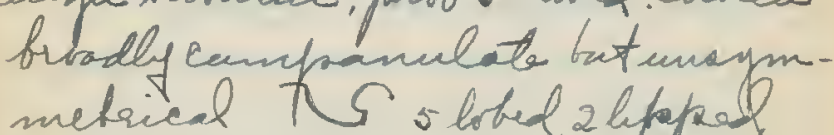

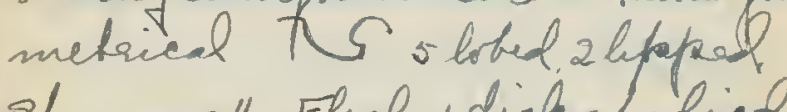
stanens 4. Fleaby diah atulied - lifed chary 2 celledwot nlei m praital placentar. 
4-15-29 Sapunder Saponaria. L Tree at so-eacterene of Fiv. Hoppital prounde tearner Yoswive to hei impornal witt 6 efto hut as one lorbbat tree hs acen simple ifto fo erlected fumground. L fti to $7 \times 3 / 2$ m m petiolites $/ 8$ in long. 2 fto ral smelveate inequilatic acute base rondel iniegui. Thin but form, entire. Abre Llighthy poudenent vdrying hs only otudiel) fim the finily mitte freina, hesleath only the mulrif v latual veins afofoncht to trual bit pubermbelts dinony to touch. Fis on parides

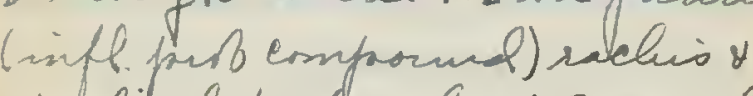
pudicela puhderulant. Beancles priple sunftendel by a suall bract shich remains on wachio meder scar noteacily

detachbler liobing libe small fasotuherance qractis. Pachio as Colletes $7 \mathrm{in} \ln \mathrm{A}$ wot the reas $v$ beacts abmet $1 / 4$ in apant at wery base $v$ Clain tojetter at typ. For barne m urhat reenso a sholt tranch $1 / 4$ in Ittion sachis s foeliceled $1 / 8$ m. Fr. fhaly. 3-lohed (but wa adorojty untervelopel the langest s/yiselor hy ahuat in unde. Fr yelloviale brow consed uncta yellow bais which readily rub of tor wrinlale Pattin stage.) Superis to calyx. Seel bla eh, rattiu fodn shapale to $9 / 8$ in. Pulpoffuchas stictoy juice, adhevirs in dryin decidebly sapomifying (T nstais hando in good tho Hin Attur which is mycleanaing). One suel was $1 / 2$ in hyahel scar ax ble. In me fr sued rattlelas tho' in pard. 
4-17-29 Lavatera trimeatris" see eavier. St.lirsute as are pect. oped. Lis to 4 in sums to aforx, puherent

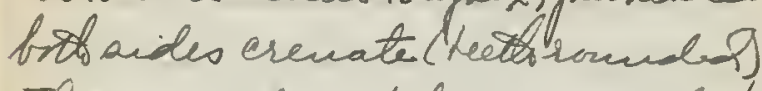
Il 2 in unde patals roxe pinlsfinely atripel wots whiste, darlatre on clow, ith tufff white hairs on lach side iclaw.(cluws notlong navow ardere L.assugentiflora. Mllogy I Pubuatince montride inshere vellyx stary Puberence on pet. vunderside gls obcurely stany in part otturise

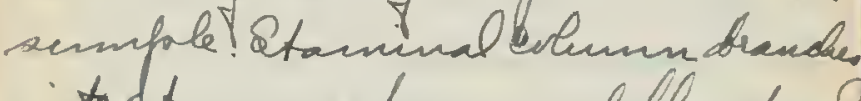
into d tamens firm muldle ufowns.

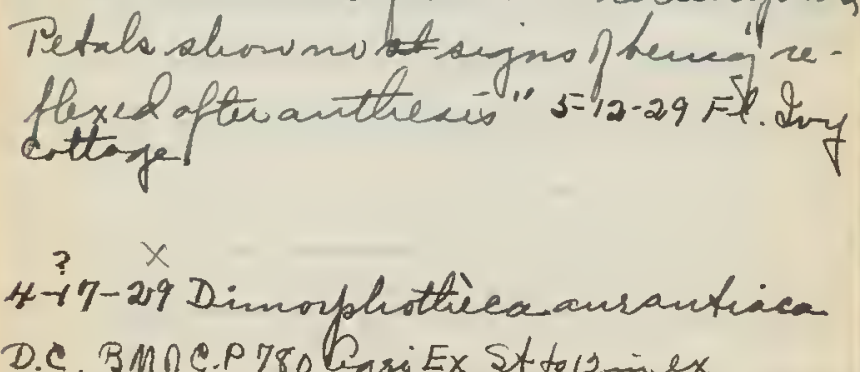
D.C. BM G.P 780 B priEx Stto12 in ex. st alightty prubeacut abriz alender. Ln

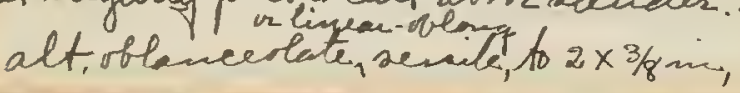

glatious, lonstorthe Labrov. Neads solitar on herminal fael. 2 sin acerso, the diats compationly small. Tays a seft orange shghth punplial m clan papilore

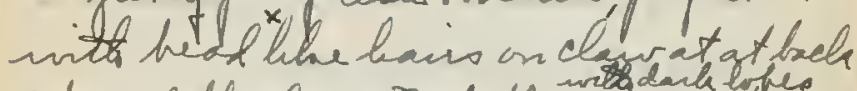

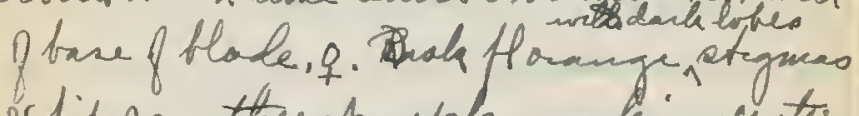

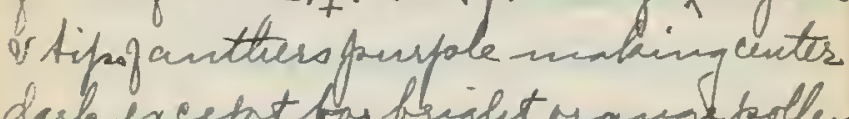
dark except fos bijest romed pollen

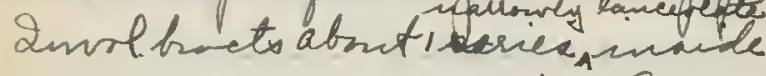
ed ges searnono narjinel. glandula unth purphibdoto. Peyachecos 3-siled y machidlyernugatel mange notches, dialaadienes flat witt

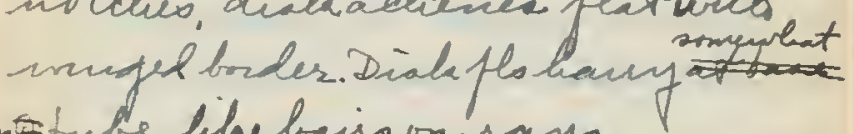
on tube lihe bair on rayo.

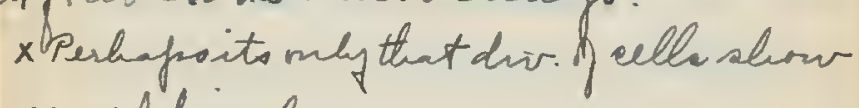
very plainly

4-17-29 Salvia Selarea L. BM M C.P. 639 Apri Ex. "Clary (Puple tipfel)"

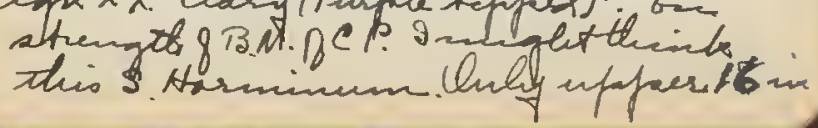


studied. Ole this hos seem mone "illong to orate." than "bordly ovate" iv mly alijetly" coslate" At inequi base hrobany, erenulate, sugroe, bhunt at a paex. Lovver fl ho sreef brod, pe abufotty decuninate ve

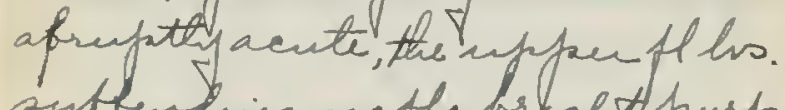
suthending ns tha bie gett purfale reing, laiger thon fl ho next below, acute nop accuminate not abufty

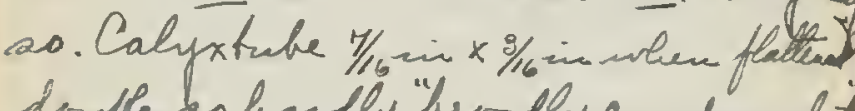
douthe bo bardly "bus dly campanulate the losver lifo 2 clift the thres alceummate, thi upper lifs 4 torthed and 2 loteral ahas p tectt wuto which vensare forrlonged. Calyx 13 -ifts thsupper dipo-rebked: 1 aldigbels. 2laterat thatdonitreach to recargin 2 lateral herminating in hest. 2

Theredant 2 and the 6 refo g lover liforrabers make lover fant s calyx lork more ritby than the infoer. Corolla tute dazly exested firm calys efper lip, purple wot darlau spotte, baing wot wito glibulariglande lita glande mealyp and uppare party fldtem (Calype green ff. hohan smeghaic Glandiclass as well.) Coulla tube githons at throat helow, lover lif whitislo, the lauge concave sniddle like having glandulou at base heneads, this laterad lokes navionts the dilated anterion postion f eonnectives alowa above thorat as tus purpale lober. The four tuttr gealyx sharp printed but mot wally spiney tipjael. 3tyle exerted beyond ifp pur lifo it cortla continuing ito cuns

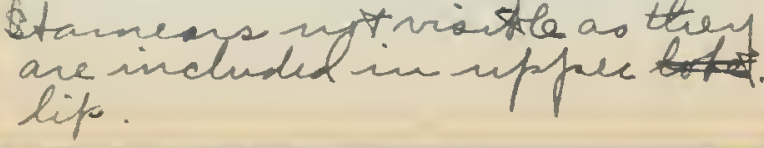


4-17-29 Cunothera sfaciosa, Nut.

OgriEx. Fl to 3 in, white tingelv vines pale frich, yellow at bare. Young capouler nd mabla lly acute, 4 -ivinged wote a ridgethet the uring. Calyx lhes linear $1 / 4 / 4$ in $x 1 / 8$ in

$x$

4-17-29 Sinsíngia sfecciona, Bust vHork. BM ZC.P694. A pri Ex.laheled "Bloxinia". Calyx $\forall$ cordla lohes, glands

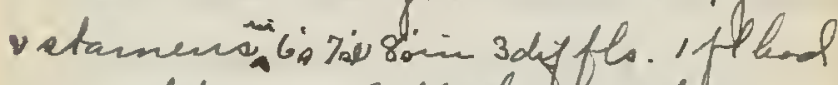
calyx lives 8 and all thu parts 6 Patf orang atrve calyx dincely puber-

4-17-29 Lodetia grandiflora, Lindl

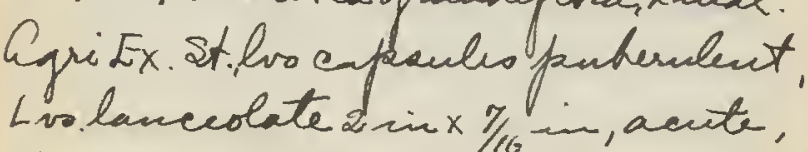
tapering mare aceately to bace, with very lour fecth (perbs simuate)

aring bawo inaide tute shorty

$x$

4-19-29 Clarkia Cegiex heat. Doutle fl' clavo nsy olest sottart pectal is merely obonste. $1 / \%$ in long by nearlyas bual, no tecta m claws and pos bleder not lobel, entive except denticulate at apax. Onttursov filimeste allreddiale. Lro entire burifae dopantes

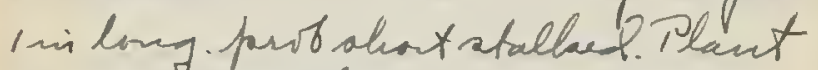
touherselent theonghast, evin at letto bany a t bare of pectale. Petalo roupinh. crimank at base. Bsib.u knghid

4-17-29 Lamólefais Tageter, $S$ DC. BMgCPx-1 Gri. Ex anderc ex. that ray H. me qonly papitose. Gehener glatures, rough woto 
4-17-29 Lilia capitata, Dougl. BMy Por6 Agri. Ex. Autters of firiente the. The 3-pact gatyma show oxhy as crella fillo. Calyx urlictich wret by

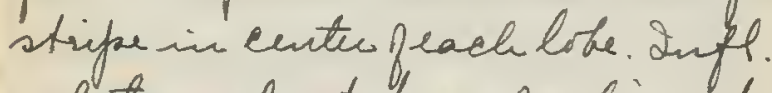
white urvet trase gealices but calyx itielf glabruss. Fl $\frac{3}{8}$ in lang

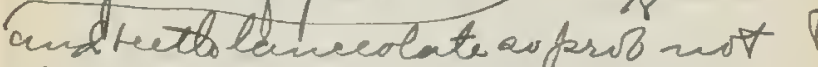

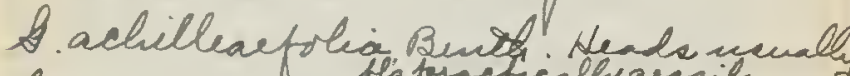
de - 1 sometisi the head branchesinto very ohn $7 / 3$ in devae iacencer flo having fochiel

4-17-29 Quctrtis strechadifina Bug. B.MyC.P. 777. Agri.Ex. Rays whete on nealyso, pale yellowat bave, fole lavendar ontaide, Diak bhish lavedas Shyle thish, prlen white Antters darher thandick fl. Dialk th aland-pubereat on ontride

crivelg

9 orter Daffurs seales frome fachenes exp thrie on outaile as ling as diak fl. Hu imeraetienes scale mot so mell derslepel is penhaps achene not nuturin Inver beata wach longer than onter rete buad hyaline tipar.

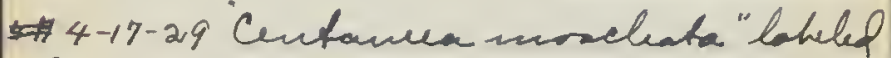

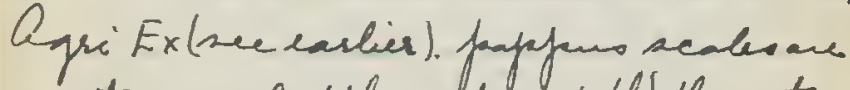

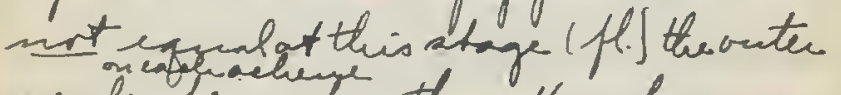
acales bengles thase $1 / 2$ as lng as

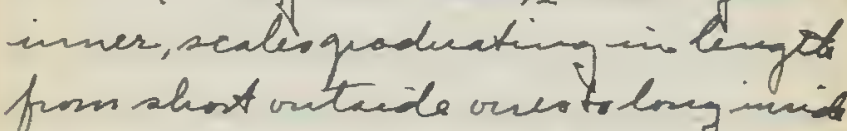

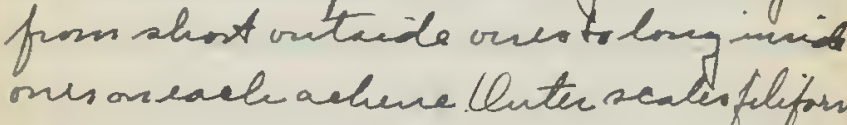
imale ones broddening townel fijo. Filimento minntely papilvae Tappous scaler greenush whete ef to

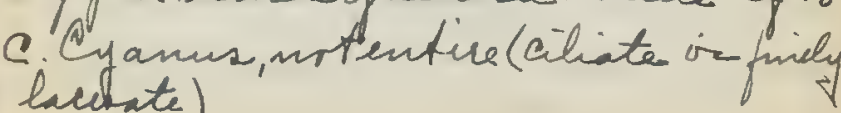


Centaniea Byamon L. fo 407 $x^{4-17-29}$ B.MqC.pb91 Cgri Ex Colors varions whit woth blue center Prabla ." frembe "

Bhe wot dache blue center Deeprnarom noth sanne centu. Tla - - . . .

Purfaluah - ...

Pald blice vots puyphile cestu Pay H llutride fed pinlerwhite mixis If " . She $v "$ Filiments glabrus wrob reng of antter. Oppandazes Nmes insol

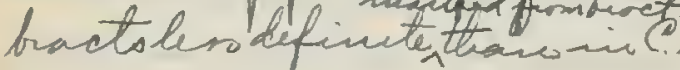
The numbrats purplish below the brom lacented Rifod. Pappuscealea

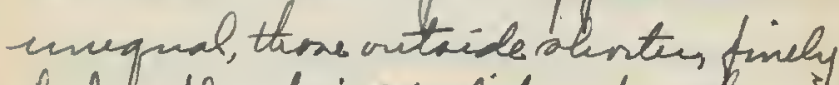
A bratly, bijhtwlite a tantrenio Ochenes slughtybaing bit much less sottan inc mbebata 


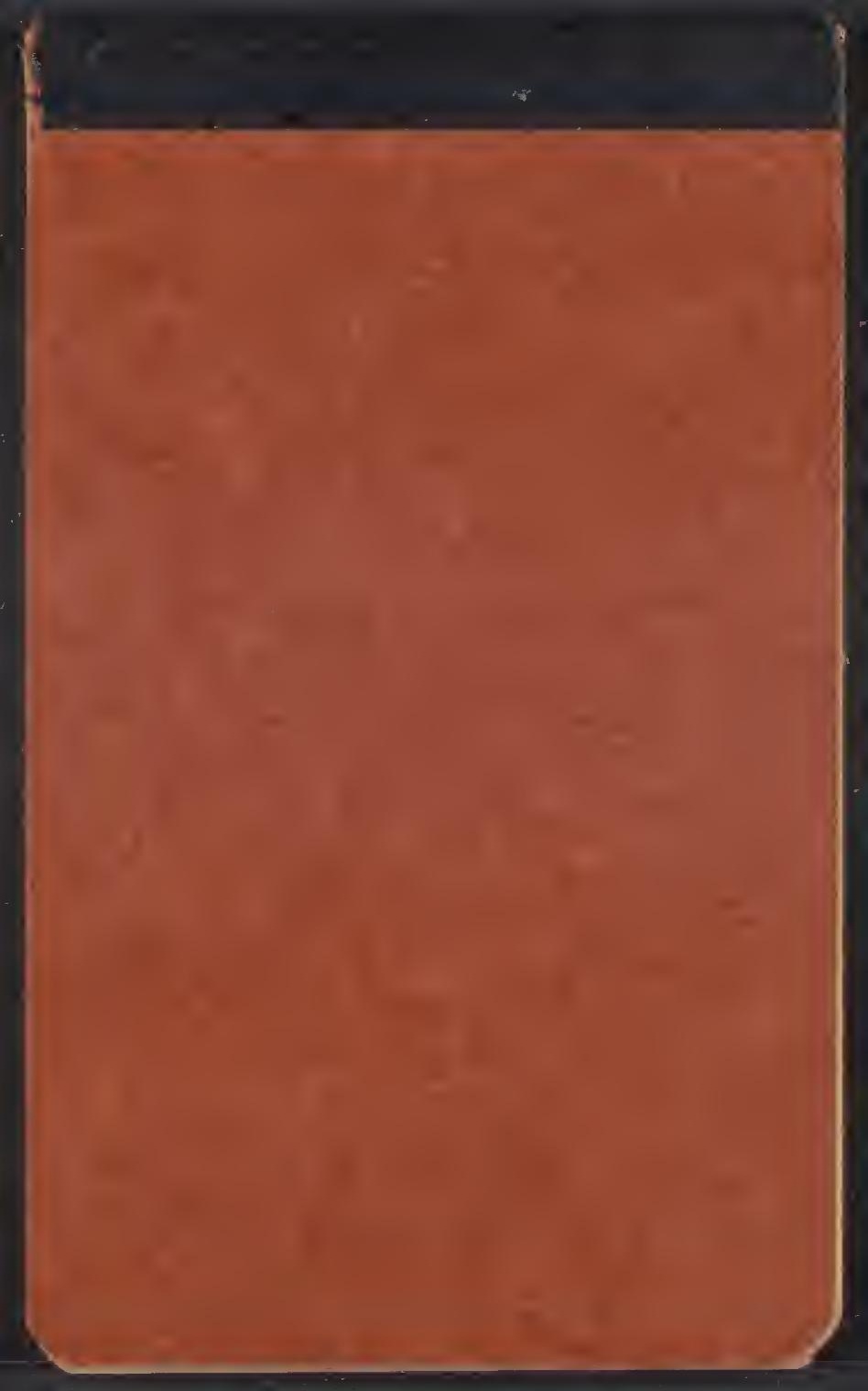

